\title{
A Methodology to Model Environmental Preferences of EPT Taxa in the Machangara River Basin (Ecuador)
}

\author{
Rubén Jerves-Cobo 1,2,3,*, Gert Everaert ${ }^{1}$, Xavier Iñiguez-Vela ${ }^{4}$, Gonzalo Córdova-Vela ${ }^{4}$, \\ Catalina Díaz-Granda ${ }^{5}$, Felipe Cisneros ${ }^{3}$, Ingmar Nopens ${ }^{2}$ and Peter L. M. Goethals ${ }^{1}$ \\ 1 Laboratory of Environmental Toxicology and Aquatic Ecology, Department of Applied Ecology and \\ Environmental Biology, Ghent University, Coupure Links 653, 9000 Ghent, Belgium; \\ gert.everaert@ugent.be (G.E.); peter.goethals@ugent.be (P.L.M.G.) \\ 2 BIOMATH, Department of Mathematical Modelling, Statistics and Bio-informatics, Ghent University, \\ Coupure Links 653, 9000 Ghent, Belgium; Ingmar.Nopens@UGent.be \\ 3 PROMAS, Programa para el manejo del agua y del suelo, Universidad de Cuenca, \\ Av. 12 de abril s/n y Agustín Cueva, 010103 Cuenca, Ecuador; felipe.cisneros@ucuenca.edu.ec \\ 4 Asociación de Consultores Técnicos ACOTECNIC Cia. Ltda. Ecuador, \\ Aguaruna s/n y Autopista Cuenca Azogues, 010109 Cuenca, Ecuador; \\ xiniguez@acotecnic.com (X.I.-V.); gcordova@acotecnic.com (G.C.-V.) \\ 5 Empresa Pública Municipal de Telecomunicaciones, Agua Potable, Alcantarillado y Saneamiento-ETAPA \\ EP. Ecuador, Benigno Malo No. 7-78 y Mariscal Sucre, 010101 Cuenca, Ecuador; cdiaz@etapa.net.ec \\ * Correspondence: Ruben.JervesCobo@UGent.be or rubenf.jervesc@ucuenca.edu.ec; \\ Tel.: +32-9-2643708 or +593-9-999070153
}

Academic Editor: Benoit Demars

Received: 28 December 2016; Accepted: 3 March 2017; Published: 8 March 2017

\begin{abstract}
Rivers have been frequently assessed based on the presence of the EphemeropteraPlecoptera-Trichoptera (EPT) taxa in order to determine the water quality status and develop conservation programs. This research evaluates the abiotic preferences of three families of the EPT taxa Baetidae, Leptoceridae and Perlidae in the Machangara River Basin located in the southern Andes of Ecuador. With this objective, using generalized linear models (GLMs), we analyzed the relation between the probability of occurrence of these pollution-sensitive macroinvertebrates families and physicochemical water quality conditions. The explanatory variables of the constructed GLMs differed substantially among the taxa, as did the preference range of the common predictors. In total, eight variables had a substantial influence on the outcomes of the three models. For choosing the best predictors of each studied taxa and for evaluation of the accuracy of its models, the Akaike information criterion (AIC) was used. The results indicated that the GLMs can be applied to predict either the presence or the absence of the invertebrate taxa and moreover, to clarify the relation to the environmental conditions of the stream. In this manner, these modeling tools can help to determine key variables for river restoration and protection management.
\end{abstract}

Keywords: generalized linear models; predictive models; decision support in water management; generalized linear modeling

\section{Introduction}

The composition of the benthic macroinvertebrate communities can reflect the ecological quality of surface waters over time as pollution induces systematic shifts in community composition $[1,2]$. Biological monitoring to assess river water health has been in use for more than a century. Nevertheless, in developing countries, this procedure was introduced and subsequently developed only recently [3]. With biological samples, it is possible to predict the average values of chemical parameters over a period of time, when their accruing effects have been more pronounced in the biota [2]. 
For evaluation of the ecological water quality of rivers and lakes, some metrics based on taxonomic macroinvertebrate community composition have been developed, such as \% EphemeropteraPlecoptera-Trichoptera (\% EPT), \% scrapers, taxa richness and Biological Monitoring Working Party (BMWP) $[1,4]$. The latter index, which was developed in England and has been adapted to tropical countries, is a procedure to determine the water quality classes based on the score of sensitivity to organic pollution of the taxa found in water bodies [5-7]. The EPT taxa are often used because these families are the most sensitive orders and their richness is related to water quality, in particular, mainly to oxygen deficiency and environmental degradation [8-10].

Few studies have been conducted to understand the environmental preferences of macrobenthos in the high altitude Andes, in which some parameters have been identified as possible predictors of the presence of taxa. For instance, Ríos-Touma, et al. [11] found a relation between macroinvertebrate community composition and flow stability velocity and their variation in both dry and rainy seasons. Jacobsen and Marín [12] principally analyzed the presence of the EPT taxa in relation to temperature and oxygen saturation. The same authors, in other research performed in Ecuador, found that the relation between the EPT taxa with the total of invertebrate fauna diminishes with the altitude [13]. Other research in the Andes indicated that the effect of organic pollution on macrobenthos was more evident during the dry season in comparison to the rainy season [14]. However, other abiotic conditions that could have an effect on the environmental preference of macroinvertebrates, especially with regard to the sensitivity of EPT taxa were not investigated in these studies.

Prediction of the distribution of species based on biotic environmental conditions has been done through the modeling of running water. These models are now recognized as the core of predictive ecology and are powerful tools in conservation planning. The approach of these models is to predict the presence/absence or abundance of a species in relation to physicochemical variables and biotic and abiotic conditions collected in a specific habitat $[15,16]$. Predicting the composition and distribution of macrobenthos communities in rivers is not a simple exercise due to the non-linear behavior of the ecosystem and the complexity of biotic and abiotic variables [1,2,17]. For ecological modeling, techniques such as artificial neural networks (ANNs), Bayesian belief networks (BBNs), classification and regression trees (CTs and RTs), genetic algorithms (GAs), logistic regressions (LRs) and support-vector machines (SVMs) have been used [16,18]. The developed models can be a comprehensive way to assess, with high reliability, the impact of an anthropogenic source in rivers, which can be helpful for decision support systems in river basin management [1].

In this article, we aim to determine which physicochemical parameters are related to the occurrence of three sensitive families, one of each order of the EPT taxa, in the Machangara River Basin in Ecuador. To do so, environmental and biological variables were collected, which were the basis of the construction of three generalized linear models (GLMs). Furthermore, we discuss the ecological relation between the selected predictors and their corresponding taxon, as well as the potential application and restriction of these models.

\section{Materials and Methods}

\subsection{River Basin}

The Machangara River is an Andean mountain river, which is an affluent of the Cuenca River. It is about $37 \mathrm{~km} \mathrm{[19]} \mathrm{in} \mathrm{length} \mathrm{and} \mathrm{at} \mathrm{the} \mathrm{end} \mathrm{of} \mathrm{its} \mathrm{path,} \mathrm{crosses} \mathrm{the} \mathrm{city} \mathrm{of} \mathrm{Cuenca,} \mathrm{located} \mathrm{in} \mathrm{the}$ southern Province of Azuay in Ecuador (Figure 1). The estimated population in Cuenca in 2015 was about 370,000 inhabitants [20]. It is also the main urban center in the study area. The Cuenca River Basin is part of the Hydrographic Demarcation Santiago, one of the Amazon Effluents.

This study focuses on the Basin of the Machangara River and its sub catchments. The study area is about $325 \mathrm{~km}^{2}$, of which $79.1 \%$ is forest protected by the Ecuadorian Government, $8.9 \%$ is a mosaic between urban area, pastures and crops, $7.1 \%$ is used as pastures, $2.4 \%$ is urban area, $1.1 \%$ is water bodies and $1.4 \%$ is bare soil (Figure $2 \mathrm{~A}$ ). This basin is regulated all year long by the presence 
of the two hydroelectric power plants, with their respective dams, Labrado and Chanlud, situated in the upper area of the catchment, upstream from Cuenca City. Water is extracted from the catchment basin for use primarily as a supply of drinking water, agriculture irrigation, and to a lesser extent, for industrial use. The altitude of the basin varies from 2440 to $4420 \mathrm{~m}$ above sea level (MASL) and its mean altitude is 3557 MASL. The average annual rainfall in the basin varies between $877 \mathrm{~mm}$ and $363 \mathrm{~mm}$ per year, while the average annual temperature fluctuates between $16.3{ }^{\circ} \mathrm{C}$ and $9.0^{\circ} \mathrm{C}$ in the lower and upper areas respectively [21,22]. Two seasons are present during the year, the rainy from the middle of February until the beginning of July and the dry season during the rest of the year. The average flow of the Machangara River measured from 1964 to 2010, before discharging into the Tomebamba River, was $8.4 \mathrm{~m}^{3} \cdot \mathrm{s}^{-1}$, the average minimum was $5.3 \mathrm{~m}^{3} \cdot \mathrm{s}^{-1}$ in August and the average maximum being $14.6 \mathrm{~m}^{3} \cdot \mathrm{s}^{-1}$ in May [23], cf. Figure A1 in Appendix for monthly averages.

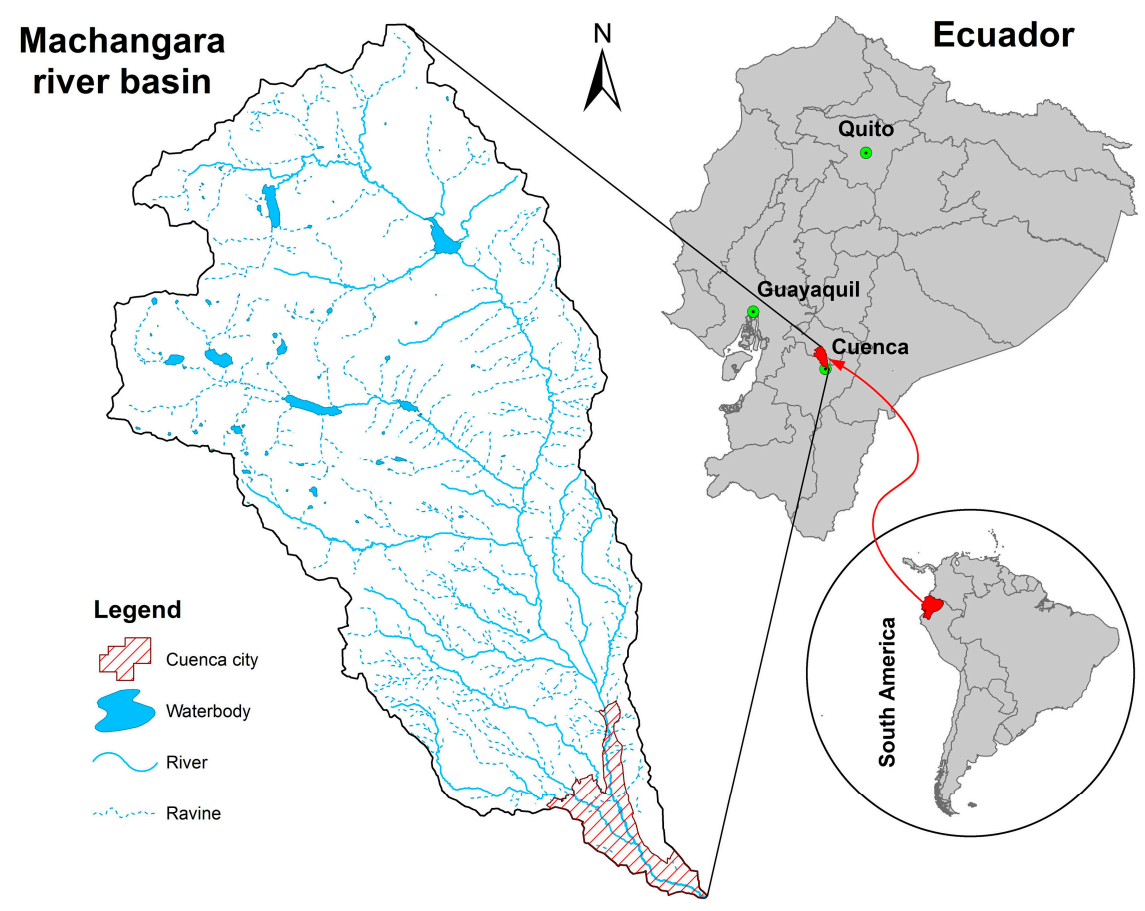

Figure 1. Location of the Machangara Basin in Ecuador.

Despite the combined sewage system in Cuenca, poor water quality results were obtained along parts where the river flows through the city. This is mainly due to some sewage networks and industrial pollution points that are discharging in certain locations along the river and its tributaries that are affecting the water quality of these streams $[19,24]$. Moreover, discharges from combined sewer overflows (CSOs) events, when wet-weather flows exceed the sewage treatment plant capacity, as well as the surface water outfalls (SWO), cause the degradation of physicochemical and biological quality [8,25-27]. Similarly, pollution from agricultural and livestock runoffs transport polluted water into the rivers [28].

\subsection{Data Collection}

The dataset used in this research was collected and measured once during the rainy season in February and March 2012, while the validation data set was sampled in the last half of July 2015 in dry season. The study considered 33 sampling locations (Figures 2 and A2), whose altitudes varied from 2451 to 3428 MASL. In each point, 16 physicochemical, hydraulic, microbiological and biological variables were measured (Table 1). The locations were chosen along the catchment according to land use (Figure 2A). 


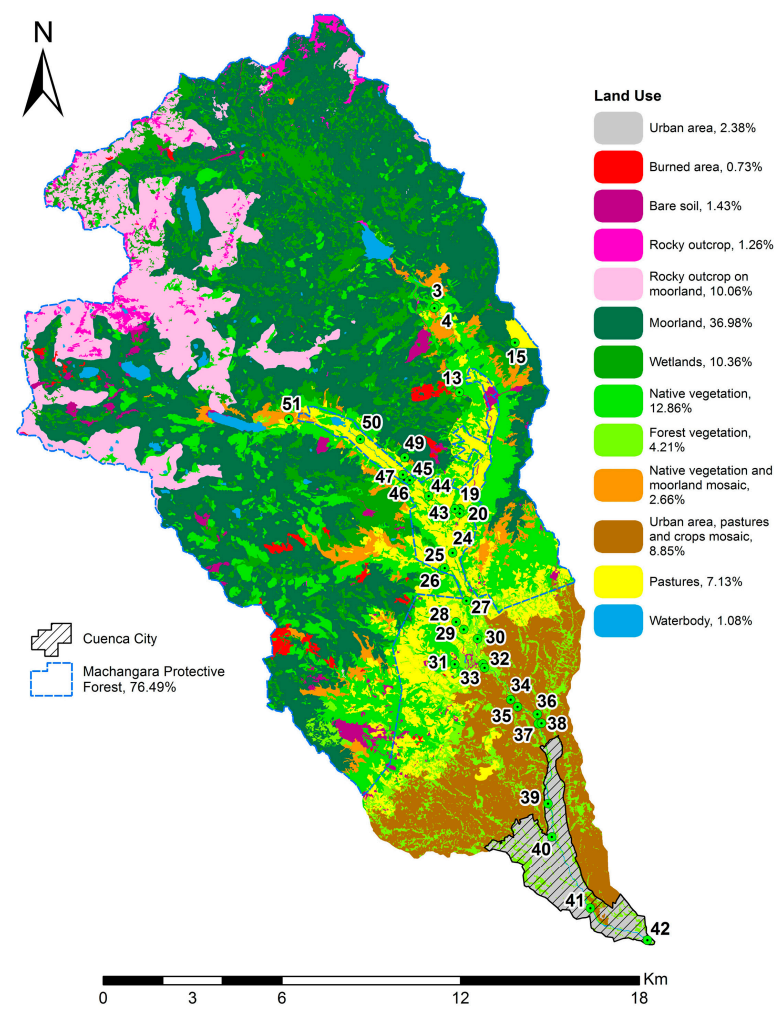

(A)

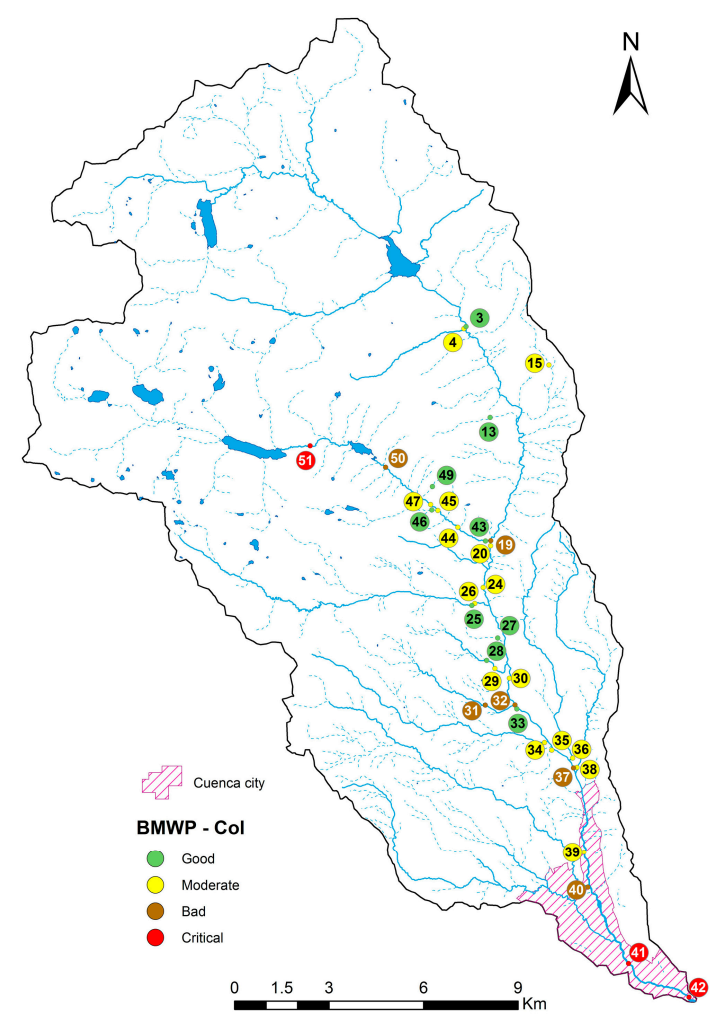

(B)

Figure 2. Sampled site locations with (A) land use; (B) Biological Monitoring Working Party score adapted to Colombia (BMWP-Col) qualification.

Table 1. Summary of the physical, chemical and microbiological data collected in the Machangara Basin in Ecuador based on 33 samples in 2012.

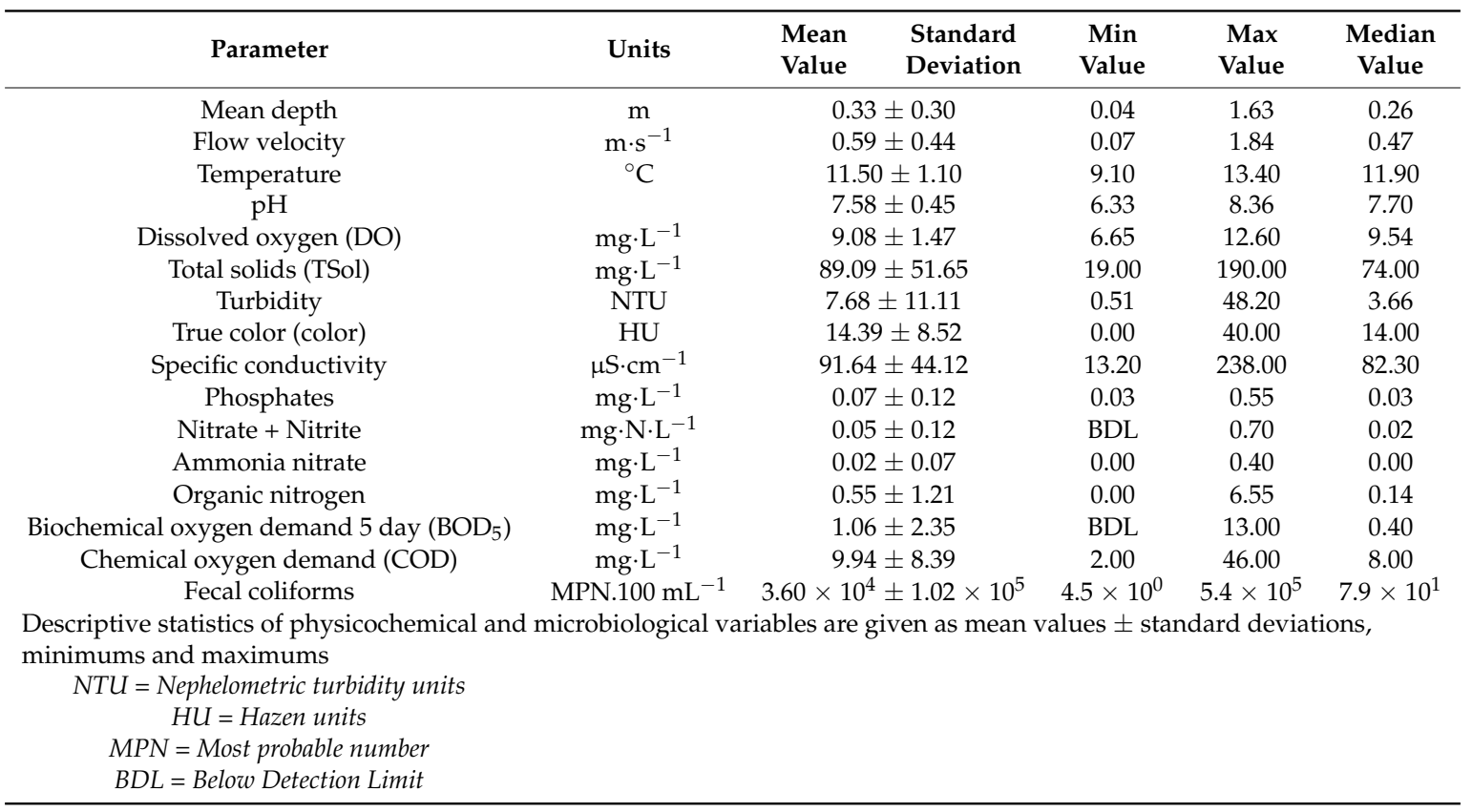

The samples of benthic macroinvertebrates were taken from the river and their tributaries by using the kick-sampling procedure. This method is applied by shuffling the feet walking backwards against a current while holding a standard net (inlet area $575 \mathrm{~cm}^{2}$, mesh size $900 \mu \mathrm{m}$, depth $27.5 \mathrm{~cm}$ ) 
against the current for six minutes in an area of $5 \mathrm{~m}^{2}$ [29-31]. The sampling was performed in a stretch of about 10-20 m of length, in different aquatic habitat. Thirty-six taxa of macroinvertebrates were identified up to family level with the help of a stereoscope and specific reference materials [32-34]. At each sampling location, to assess the water quality, the Biological Monitoring Working Party score adapted to Colombia (BMWP-Col) was calculated [7,33,35] (Figures 2B and A2). The sensitivity score ranges from one (for very tolerant taxa) to 10 (for the most sensitive families). The BMWP-Col, which is measured from one to 120, gives a five water quality classification in function of the sum of sensitive scores obtained in each location: bad ( $\leq 15)$, deficient (16-35), moderate (36-60), good (61-99), very good (100-120) [33,35].

\subsection{Model Species}

Three macroinvertebrate families present in the river basin, which are pollution-sensitive based on the BMWP-Col, were selected. These taxa were Baetidae (Ephemeroptera), Leptoceridae (Trichoptera) and Perlidae (Plecoptera). Baetidae belong to the mayfly family and their tolerance score (TS) to pollution is 6. Leptoceridae are part of the caddisflies family and have a TS equal to 8. Perlidae are part of the stoneflies family and have a TS of 10 .

\subsection{Model Development, Selection, Validation and Optimization}

In this research, the presence/absence of three sensitive macroinvertebrate taxa, described above, was associated with a physicochemical water quality condition, using a generalized linear model (GLM) with binomial adjustment. The presence or absence of a species, in connection with explanatory variables such as environmental conditions, has been frequently modeled as binary response using GLM [36-38]. The GLMs were developed in order to conceptualize the environmental preferences of macroinvertebrates. Three different GLMs were constructed, thus one model for each family that can be used as input for the environmental suitability quantifications.

For starting the data exploration and analysis, boxplots linked to the presence and absence of a family in relation to the amplitude of physicochemical variables were constructed [36].

Collinearity between explanatory variables were computed with a non-parametric Spearman rank correlation coefficient, which is regularly used in ecology because this parameter makes no assumptions about linearity between the two variables [36,39]. Variables are not omitted for the construction of a model, when the Spearman correlation coefficient is lower than 0.80 , since this means that no strong correlation is detected and no redundant variables are identified $[36,40,41]$.

In a GLM, the distribution of the response variable $Y_{i}$ also expresses the mean and variance of $Y_{i}$. As a result, the expected mean and variance of $Y_{i}$ are given by: $E\left(Y_{i}\right)=\pi_{i}$ and $\operatorname{var}\left(Y_{i}\right)=\pi_{i} \times\left(1-\pi_{i}\right)$. Where, $\pi_{i}$ signifies the probability that taxa $i$ are present and $\left(1-\pi_{i}\right)$ is the probability that they are absent. The models were composed using Equation (1), in which $X_{n i}$ means the explanatory variables, while $\alpha$ and $\beta_{i}$ are regression parameters [36].

$$
\mathrm{E}\left(Y_{i}\right)=\pi_{i}=\frac{e^{\left(\alpha+\beta_{1} \times X_{1 i}+\beta_{2} \times X_{2 i}+\cdots \ldots+\beta_{n} \times X_{n i}\right)}}{1+e^{\left(\alpha+\beta_{1} \times X_{1 i}+\beta_{2} \times X_{2 i}+\cdots \ldots+\beta_{n} \times X_{n i}\right)}}
$$

For the assessment of the goodness-of-fit and choice of models, the Akaike information criterion (AIC) was analyzed. AIC is a statistical performance criterium that is a trade-off between model complexity and model accuracy criteria. Thus, the best model, which has the lowest value of AIC, tends to fit closest to reality [42].

The effects of the input variables (i.e., abiotic variables) on model performance were assessed in order to identify which ones have influence on the presence or absence of a family. This was done by consecutively eliminating the least important input variables that had the highest $p$-value. When beneficial for model performance, previously removed variables were introduced again [43], in seeking the lowest AIC. This stepwise input variable selection procedure in the construction process of the 
three models was tested to find the lowest AIC. Each model had its own explanatory variables with which the presence or absence of an individual taxon was predicted.

For each of the developed models, the adjusted $R^{2}$ was reported, which is a likelihood ratio index in a logistic regression model that is analogous with the $R^{2}$ used in multiple linear regression techniques [44]. All GLMs were fitted with an independent correlation matrix and all statistical tests were performed at the 5\% significance level. The GLMs and the boxplots were constructed in $R$ [45].

Finally, the model was validated with information collected in 14 points of the same basin in June of 2015 (dry season). The accuracy of the validation set for each GLM was calculated as the adjusted $R^{2}$, which was determined as a relation between the correct predictions divided by the total points analyzed.

\section{Results}

\subsection{Data Exploration}

The flow had a wide variation with minimal values lower than $0.1 \mathrm{~m}^{3} \cdot \mathrm{s}^{-1}$ in small streams located in the upper area of the basin and maximum values of $23.1 \mathrm{~m}^{3} \cdot \mathrm{s}^{-1}$ in the lowest areas of the catchment, close to the city. The flow velocity, due to the mountainous terrain and the slope difference, varies from a very slow flow $\left(0.07 \mathrm{~m} \cdot \mathrm{s}^{-1}\right)$ in flat areas to high velocities $\left(1.84 \mathrm{~m} \cdot \mathrm{s}^{-1}\right)$ in steep lands (Figure A3A). The water temperature was colder $\left(9.1^{\circ} \mathrm{C}\right)$ in the upper mountain regions than in the lower regions $\left(13.4^{\circ} \mathrm{C}\right)$ (Figure A3A). The pollution from anthropogenic origin measured as $\mathrm{BOD}_{5}$ (Figure A3A), $\mathrm{COD}$ (Figure A3B) and fecal coliforms (Figure A3A) was low. The maximum concentration of these pollutants was 13 and $46 \mathrm{mg} \cdot \mathrm{L}^{-1}$ and $5.4 \times 10^{5} \mathrm{MPN} .100 \mathrm{~mL}^{-1}$ respectively. Values that were in the range of an analysis done by Esquivel, et al. [24], with more than 200 physicochemical samples taken on a quarterly basis by ETAPA-EP from 1984 to 2006. Because the fecal coliforms exhibited a wide variation, the analysis was executed on a logarithmic scale. For the most part, the $\mathrm{pH}$ remained in the basic zone, with three points with a level less than 7 . The minimum value of this parameter was 6.33, while the maximum value was 8.36 (Figure A3). The maximum value of the color was $40 \mathrm{HU}$, which was mainly vegetable in origin, due to the presence of moorland, wetlands and native vegetation (Figure A3B). The conductivity in general was low, with values from 13.2 to $238 \mu \mathrm{S} \cdot \mathrm{cm}^{-1}$ (Figure A4C). The dissolved oxygen (DO) was high with a minimum of $6.7 \mathrm{mg} \cdot \mathrm{L}^{-1}$ (Figure A3C). This could be due to the high re-aeration capacity because of the high flow velocity and the low depth of the water in the river. When the Machangara River passes through the urban area, the maximum values of total solids (Figure A4A), and turbidity (Figure A4B) were registered: respectively at $190 \mathrm{mg} \cdot \mathrm{L}^{-1}$ and 48.2 NTU. In general, the river had low depth, with only one place in the flat area located in the city, where this value reached more than $1.0 \mathrm{~m}$ (Figure A4D). Other pollutants such as the organic nitrogen (Figure A3C), the Nitrate/Nitrite, the Ammonia Nitrogen and the Phosphates (Figure A4D) had low concentrations, with maximum values of $6.55 \mathrm{mg} \cdot \mathrm{L}^{-1}, 0.70 \mathrm{mg} \cdot \mathrm{L}^{-1}, 0.40 \mathrm{mg} \cdot \mathrm{L}^{-1}$ and $0.55 \mathrm{mg} \cdot \mathrm{L}^{-1}$ respectively. These points were registered where the land was used for pasture or crops. An overview of the measured physicochemical, microbiological and biological variables can be seen in Table 1 .

Poor biological water quality was registered in the stretches after the dams of the two hydroelectric plants. The main cause of poor water quality here is hydropeaking. By contrast, good water quality results were found in the upstream locations of the basin where there is a low human presence. While, eight places located in the high land natural forest had moderate water quality, two locations in the reach flowing through the city registered poor biological water quality.

Regarding the fluctuations of the abiotic variables and their relation to the BMWP-Col, we concluded that, when the flow velocity in the studied rivers was higher than $1.3 \mathrm{~m} \cdot \mathrm{s}^{-1}$, the poorest biological water quality was found (i.e., BMWP-class V: bad) (Figure 3C). The highest concentration of the organic pollutants $\mathrm{BOD}_{5}$ (Figure A5A), COD (Figure 3A) and fecal coliforms (Figure A5B) was registered closest to the city, which agreed with the poorest biological quality (class V). High flow velocities and increased levels of organic matter were detected in only one point close to the city, 
leading both parameters to register low biological water quality. In relation to the temperature, the biological water quality tended to be better with lower temperatures (Figure 3D). It could be because in elevated regions, the anthropogenic pollution is lower and a protected area is present. The $\mathrm{pH}$ (Figure A5C), the color (Figure A5D) and the conductivity (Figure 3B) do not have a visible impact on the BMWP-Class.

A

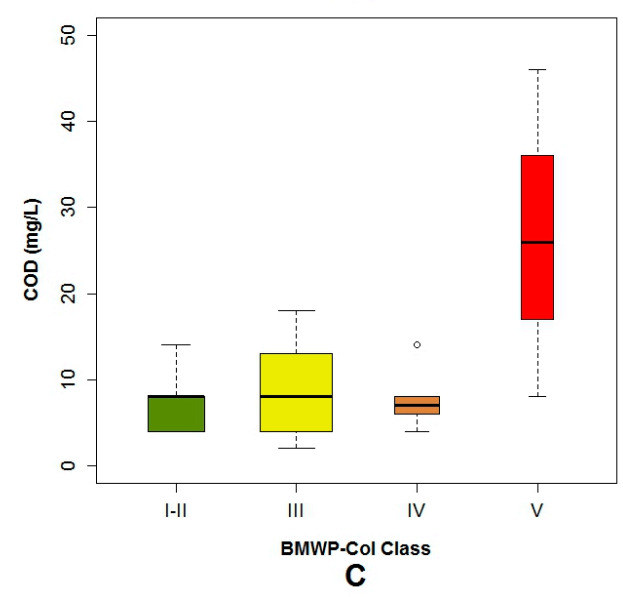

B

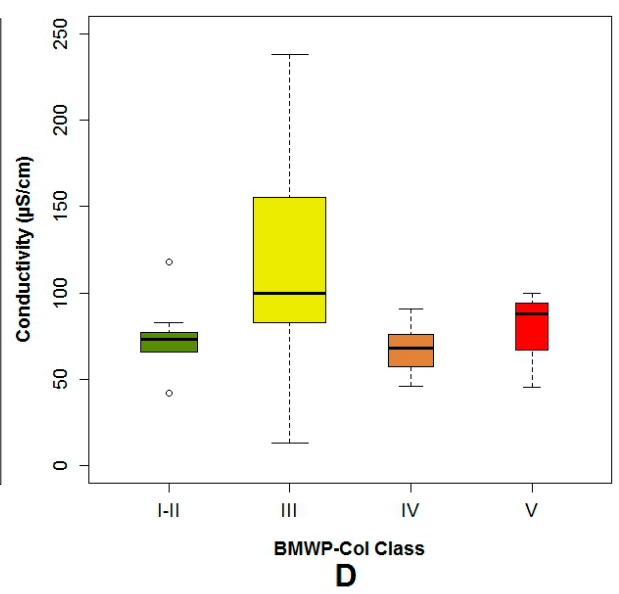

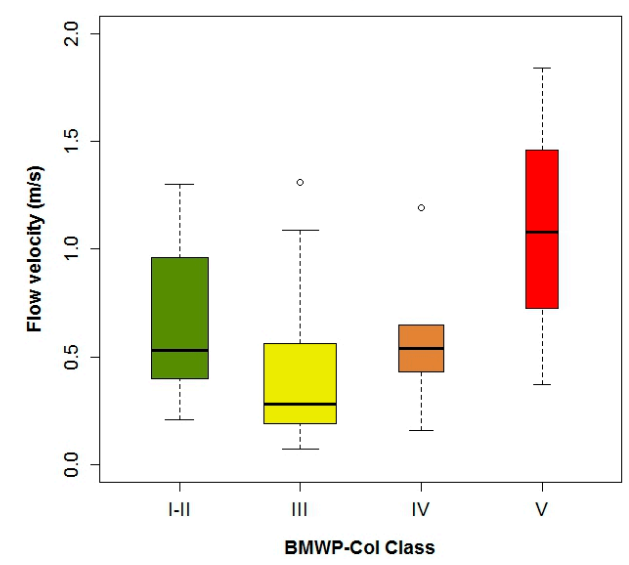

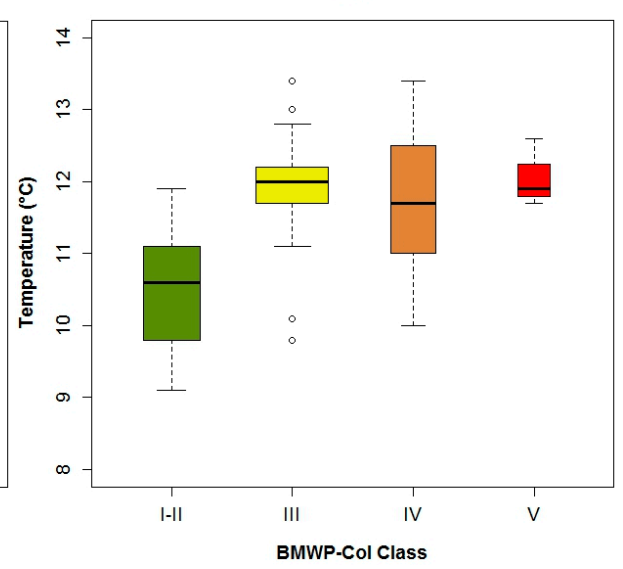

Figure 3. Boxplots of the BMWP-Col class with the main explanatory variables of the three models: (A) chemical oxygen demand (COD); (B) conductivity; (C) flow velocity and (D) temperature.

When the BMWP-Col is analyzed with the selected EPT taxa, we determined that Baetidae was present in all biological classes (Figure 4A). While, Leptoceridae was found when the BMWP-Col varied from class I to IV (Figure 4B) and Perlidae was present in the highest biological classes (i.e., Class I, II and III) (Figure 4C).

\subsection{Correlation Analysis}

Regarding the collinearity analysis (Tables 2 and A1), no variables were omitted for the construction of the three models. Four cases in which the absolute value of correlation coefficient is greater than 0.50 but less than 0.80 , were detected. For the Leptoceridae model, two values higher than 0.50 were found, COD with $\mathrm{BOD}_{5}(r=0.61, p<0.001)$ and $\mathrm{Log}$ Fecal Coliforms with $\mathrm{BOD}_{5}(r=0.57$, $p<0.001)$. In the Baetidae model, only one occurrence of the correlation coefficient higher than 0.50 was established, color with $\operatorname{COD}(r=0.63, p \leq 0.001)$. One of the high values of correlation coefficient is color with $\mathrm{BOD}_{5}(r=0.51, p=0.002)$, which is not in relation to any model. 
A

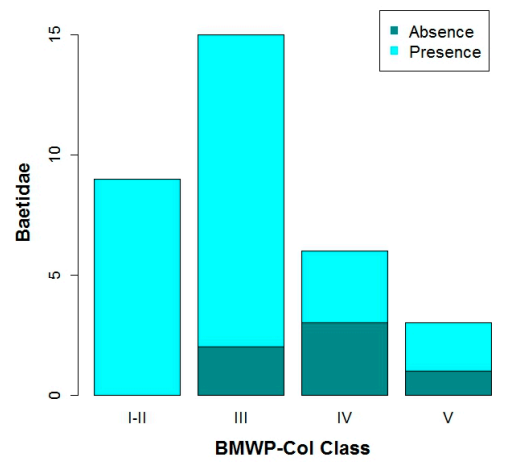

B

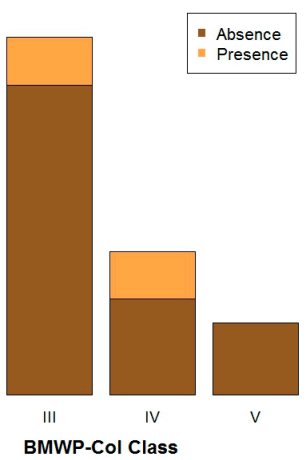

C

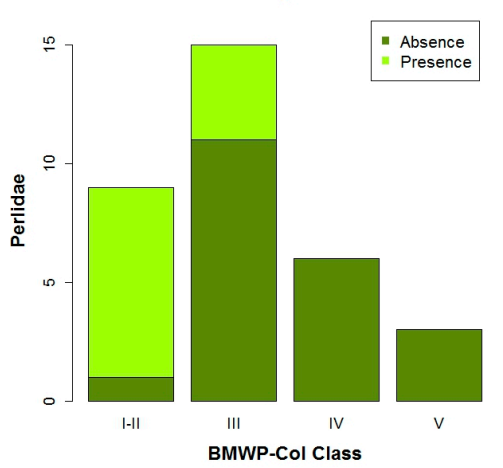

Figure 4. Bar plots of the BMWP-Col class with the number of the samples in which the chosen macrobenthos were present or absent: (A) Baetidae; (B) Leptoceridae and (C) Perlidae.

Table 2. Spearman correlation coefficients of the explanatory variable used to construct the generalized linear models (GLMs).

\begin{tabular}{ccccccccc}
\hline Explanatory Variable & BOD $_{\mathbf{5}}$ & COD & Conductivity & $\begin{array}{c}\text { Flow } \\
\text { Velocity }\end{array}$ & $\begin{array}{c}\text { Log Fecal } \\
\text { Coliforms }\end{array}$ & pH & $\begin{array}{c}\text { True Color } \\
\text { (Color) }\end{array}$ & $\begin{array}{c}\text { Water } \\
\text { Temperature }\end{array}$ \\
\hline BOD $_{5}$ & 1.00 & & & & & & & \\
COD & 0.61 & 1.00 & & & & & & \\
Conductivity & 0.06 & 0.01 & 1.00 & & & & & \\
Flow velocity & 0.11 & 0.26 & -0.29 & 1.00 & & & & \\
Log fecal coliforms & 0.57 & 0.45 & 0.36 & 0.19 & 1.00 & & & \\
pH & 0.21 & 0.15 & 0.16 & 0.12 & 0.40 & 1.00 & & 1.00 \\
True color (color) & 0.51 & 0.63 & -0.31 & 0.29 & 0.33 & -0.08 & 1.00 & \\
Water temperature & 0.48 & 0.20 & 0.30 & 0.03 & 0.26 & 0 & -0.02 & \\
\hline
\end{tabular}

\subsection{Logistic Regression Models}

Of the 16 physicochemical and microbiological variables measured in the Machangara River, only eight revealed a relation with the presence or absence in the three GLMs of Baetidae, Leptoceridae and Perlidae. These variables were flow velocity, water temperature, $\mathrm{pH}$, color, conductivity, biological oxygen demand five $\left(\mathrm{BOD}_{5}\right)$, chemical oxygen demand $(\mathrm{COD})$ and fecal coliforms (Table 3, Figures A6-A8). However, the range of preferred physicochemical conditions differed between families in relation to their specific variables. The regression coefficients of Equation (1), $p$-values and goodness-of-fit measurements of the aforementioned models are presented in Tables 3 and A2. For each of the families, the model selection procedure is summarized in Tables A3-A5.

Table 3. Regression parameters: $p$-values and goodness-of-fit measurements of the models for predicting the presence of Baetidae, Leptoceridae and Perlidae.

\begin{tabular}{|c|c|c|c|c|c|c|c|}
\hline \multirow{2}{*}{ Explanatory Variable } & \multirow{2}{*}{$\begin{array}{l}\text { Regression } \\
\text { Parameters }\end{array}$} & \multicolumn{2}{|c|}{ Baetidae } & \multicolumn{2}{|c|}{ Leptoceridae } & \multicolumn{2}{|c|}{ Perlidae } \\
\hline & & Coefficient & $p$-Values & Coefficient & $p$-Values & Coefficient & $p$-Values \\
\hline & $\mathrm{A}$ & 26.95 & 0.11 & 50.48 & 0.02 & 14.17 & 0.03 \\
\hline $\mathrm{BOD}_{5}$ & B1 & & & -12.40 & 0.06 & & \\
\hline $\mathrm{COD}$ & B2 & 0.75 & 0.10 & -1.12 & 0.05 & & \\
\hline Conductivity & B3 & 0.13 & 0.04 & -0.08 & 0.06 & 0.05 & 0.04 \\
\hline Flow Velocity & B5 & & & -12.27 & 0.04 & 2.31 & 0.17 \\
\hline Log Fecal Coliforms & B4 & & & 6.41 & 0.04 & -1.89 & 0.02 \\
\hline $\mathrm{pH}$ & B6 & & & -5.31 & 0.03 & & \\
\hline Temperature & B7 & -2.86 & 0.07 & & & -1.43 & 0.03 \\
\hline True Color (Color) & B8 & -0.41 & 0.10 & & & & \\
\hline \multirow{2}{*}{\multicolumn{2}{|c|}{$\begin{array}{c}\text { AIC: } \\
\text { Adjusted } R^{2}:\end{array}$}} & \multicolumn{2}{|c|}{22.52} & \multicolumn{2}{|c|}{26.52} & \multicolumn{2}{|c|}{34.46} \\
\hline & & \multicolumn{2}{|c|}{$59.99 \%$} & \multicolumn{2}{|c|}{$67.64 \%$} & \multicolumn{2}{|c|}{$43.46 \%$} \\
\hline
\end{tabular}


For the family of Baetidae (TS: 6), the adjusted $R^{2}$ calculated for their GLM was around $60 \%$ and the AIC value was equal to 22.5, which was the lowest of the three constructed models for the three families. These taxa were present in 27 of the 33 sampled points. The effect of conductivity $(p=0.04)$, temperature $(p=0.07)$, color $(p<0.10)$ and COD $(p=0.10)$ were associated with the probability of the occurrence of Baetidae according to the constructed GLM (Table 3). Based on the binomial model and the constructed boxplots, the likelihood of the existence of Baetidae increases with lower temperatures (Figures A9A and A6A). The effect of the color was similar, i.e., with a minor value, their possibility of presence increased (Figures 5A and A6B). Concerning conductivity, Baetidae were likely to occur at higher values (Figures A9C and A6D) compared with the other two analyzed taxa. Nevertheless, the maximum measured concentration of this variable was $238 \mu \mathrm{S} \cdot \mathrm{cm}^{-1}$, which was relatively low. A higher probability of the existence of Baetidae was associated to the measured range ( 2 to $46 \mathrm{mg} \cdot \mathrm{L}^{-1}$ ) of COD concentration, (Figures A9B and A6C). The maximum registered value of this parameter corresponded to water with relatively low pollution. The plots of the residuals vs. fitted and scale-location of the model can be seen in Figure A12A,B respectively.

A
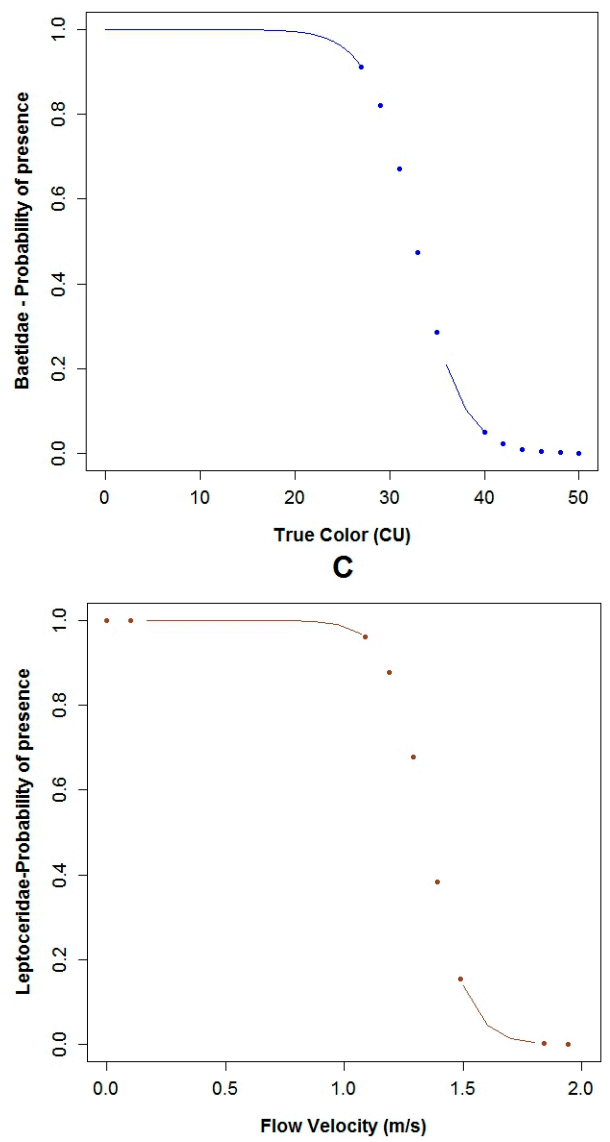

B

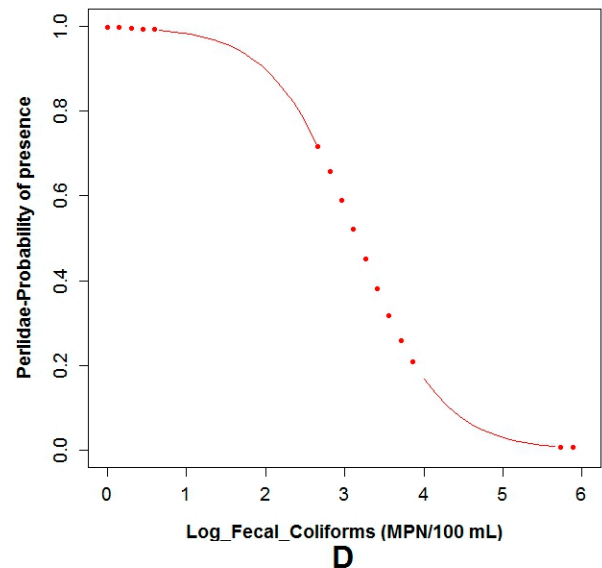

D

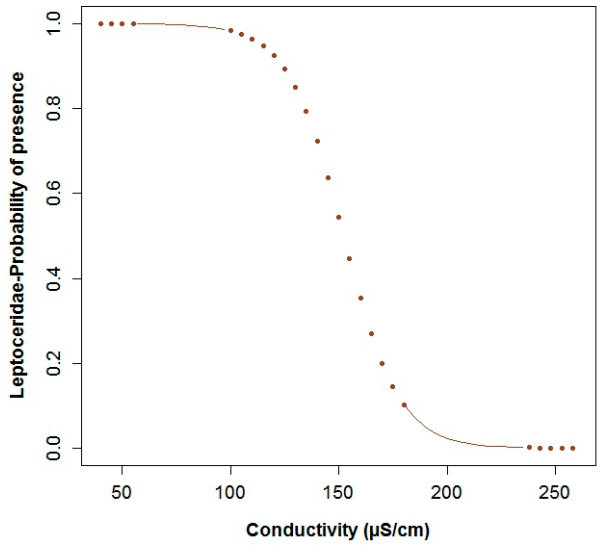

Figure 5. The probability of chosen taxa being present in relation to an explanatory variable: (A) Baetidae with color; (B) Perlidae with log fecal coliforms; (C) Leptoceridae with flow velocity; (D) Leptoceridae with conductivity. (The points in the curves indicate extrapolation outside the observed physicochemical variables range).

Regarding Leptoceridae (TS: 8), their GLM had the highest adjusted $R^{2}$ of the three analyzed models for the three taxa, with a value of $67.6 \%$ and the AIC value was equal to 26.5. This family was present in six of the 33 sampled points. The $\mathrm{pH}(p=0.03)$, flow velocity $(p=0.04)$, fecal coliforms $(p=0.04)$ expressed in log scale, $\operatorname{COD}(p=0.05), \operatorname{BOD}_{5}(p=0.06)$ and conductivity $(p=0.06)$ are the variables of the GLM related to the probability of the occurrence of this family (Table 3). The boxplots 
of Leptoceridae and their GLM reveals that the probability of the presence of these taxa is higher with low values of fecal coliforms (Figures A10A and A7A), low concentrations of COD (Figures A10B and $\mathrm{A} 7 \mathrm{E}$ ), and $\mathrm{BOD}_{5}$ (Figures $\mathrm{A} 10 \mathrm{C}$ and $\mathrm{A} 7 \mathrm{C}$ ). The probability of the existence of the aforementioned taxa is higher with neutral $\mathrm{pH}$ (Figures A10D and A7D) and when the flow velocity is lower than one meter per second (Figures $5 \mathrm{C}$ and $\mathrm{A7B}$ ). These taxa tend to be present when the conductivity is low (Figures 5D and A7F). The plots of the residuals vs. fitted and scale-location of the model can be seen in Figure A12C,D respectively.

The Perlidae (TS: 10) GLM model was characterized by the lowest adjusted $R^{2}$ value (43.5\%) and the highest AIC value (34.5) of the three constructed models for the three families. These taxa were present in 12 of the 33 sampled points. The probability of the occurrence of Perlidae in relation to the constructed GLM is associated to fecal coliforms $(p=0.02)$ expressed in log scale, temperature $(p=0.03)$, conductivity $(p=0.04)$ and flow velocity $(p=0.17)$ (Table 3$)$. Regarding the binomial model of Perlidae and their boxplots, the possibility of the presence of this family is higher with less concentration of fecal coliforms (Figures $5 \mathrm{~B}$ and $\mathrm{A} 8 \mathrm{~B}$ ). When the temperature (Figures A11A and A8A) was lower, the opportunity of occurrence of the aforementioned taxa increased. Perlidae also prefer flow velocities with values less than $1.5 \mathrm{~m} \cdot \mathrm{s}^{-1}$ (Figures A11B and A8D) and conductivity below $180 \mu \mathrm{S} \cdot \mathrm{cm}^{-1}$ (Figures A11C and A8C). The plots of the residuals vs. fitted and scale-location of the model can be seen in Figure A12E,F respectively.

The studied families: Baetidae, Leptoceridae and Perlidae, had one common variable, the conductivity, which always was below $250 \mu \mathrm{S} \cdot \mathrm{cm}^{-1}$. COD was a conjoint variable between Baetidae and Leptoceridae, albeit the amplitude of this predictor was lower when the sensitivity of the taxa was higher. Leptoceridae and Perlidae had two other mutual variables: fecal coliforms and flow velocity. For the first variable, the range was minor when the sensitivity of the taxa was greater, while for the second predictor, the value in both cases was less than $1.4 \mathrm{~m} \cdot \mathrm{s}^{-1}$. A common variable between the GLMs of Baetidae and Perlidae was the temperature, which was inferior when the sensitivity of the taxa was superior.

When the GLMs were validated with an independent data set, the accuracy of the models measured as adjusted $R^{2}$ was $86 \%$ for Baetidae, $86 \%$ for Leptoceridae and $43 \%$ for Perlidae.

\section{Discussion}

\subsection{Analysis of the Chosen EPT Taxa in Relation with the BMWP-Col}

Although the average values of measured pollutants were low in eight points located by the forest in the upper area of the basin, the biological class given for BMWP-Col was moderate. Similar findings were found in high land streams in the Andes in South America and in the Rwenzori Mountains in Africa $[12,46,47]$. This could be due to environmental stress caused by natural factors such as the disturbance of stream sites due to poor habitat conditions, the impact of heavy rains in the rainy season [12], and heavy shading, or due to hydropeaking as a result of dam operation. Other causes could be the water physicochemical characteristics in the forest sites, such as low conductivity, low turbidity, high dissolved oxygen concentration, which in combination with heavy shading could influence the low primary production [48].

The presence of Baetidae in all the BMWP-Col classes could be due to the fact that the maximum measured concentration of $\mathrm{BOD}_{5}$ was $13 \mathrm{mg} \cdot \mathrm{L}^{-1}$, a value that is relatively low, and the minimum DO concentration was high with a value of $6.65 \mathrm{mg} \cdot \mathrm{L}^{-1}$. This family was found in Thailand with concentrations of $\mathrm{BOD}_{5}$, DO and conductivity of $7 \mathrm{mg} \cdot \mathrm{L}^{-1}, 1.1 \mathrm{mg} \cdot \mathrm{L}^{-1}$ and $377 \mu \mathrm{S} \cdot \mathrm{cm}^{-1}$ respectively. In Ghana, these taxa were present with a BOD $\mathrm{B}_{5}$ of $2 \mathrm{mg} \cdot \mathrm{L}^{-1}$, DO of $4.1 \mathrm{mg} \cdot \mathrm{L}^{-1}$ and a conductivity of $1250 \mu \mathrm{S} \cdot \mathrm{cm}^{-1}$ [10], while in Turkey, Baetidae were found when BOD 5 was $8.8 \mathrm{mg} \cdot \mathrm{L}^{-1}$ [49].

When Leptoceridae were present, the BMWP-Col class varied from I to IV, despite low pollution registered, with a maximum $\mathrm{BOD}_{5}$ of $0.60 \mathrm{mg} \cdot \mathrm{L}^{-1}$ and a minimum $\mathrm{DO}$ of $6.7 \mathrm{mg} \cdot \mathrm{L}^{-1}$. Perlidae were present when the BMWP-Col was registered from Class I to III, the minimum DO was $7.0 \mathrm{mg} \cdot \mathrm{L}^{-1}$ and 
the maximum $\mathrm{BOD}_{5}$ was $0.50 \mathrm{mg} \cdot \mathrm{L}^{-1}$. Other factors such as disturbances of stream caused by the rainy season, or by the daily operation of the two dams, could have induced the lower BMWP-Col class.

\subsection{Analysis of the Explanatory Variables in Relation to Response Variables}

Our results demonstrate that GLMs can be used to select physicochemical variables that best predict the presence of the EPT taxa. These orders were chosen because those models describing environmental preference conditions of sensitive families are more reliable and valid than models for non-sensitive taxa [50]. For example, Forio, et al. [50] showed that the model constructed to predict the occurrence of the Leptophlebiidae (TS: 10) taxa, which belong to the Ephemeroptera order, was reliable, while, for the prediction of the Chironomidae (TS: 2), which belong to the Diptera order, the model was not reliable.

Conductivity was a common variable between the three analyzed taxa (Baetidae, Leptoceridae and Perlidae). This variable represents the natural mineral content of the water from both inorganic and organic origin [51]. In the first case, inert material is dragged because of precipitation and local geology, as well as inorganic pollutants from different anthropogenic sources that are leached or discharged into water bodies. However, in the second case, the organic origin is mainly due to wastewater discharges [43,52]. In agreement with the models developed in this research, conductivity has been established as one of the most critical variables to predict macroinvertebrates presence in rivers, in both tropical and temperate countries $[38,51,53]$. In this way, the caddisflies and stoneflies orders, from which Leptoceridae and Perlidae originate respectively, were reported to be present when the conductivity was relatively low [54,55]. Furthermore, D'Heygere, et al. [51] indicated that the wide range of variation of this variable expresses the high diversity existing between rivers and their stretches.

Similarly, Dissolved Oxygen (DO) is a variable that in most cases is present to predict the occurrence of macroinvertebrates [51,56,57]. Nonetheless, DO was not a variable of the three GLMs in this research, an observation that was not expected in our research hypothesis. The main cause could be that the lowest measured concentration of DO in the field was $6.65 \mathrm{mg} \cdot \mathrm{L}^{-1}(>85 \%$ oxygen saturation), a value that was enough for the presence of Baetidae. For the occurrence of Leptoceridae and Perlidae, higher concentrations of DO were necessary, values that were greater when the family was more sensitive. That is, for Leptoceridae, the minimum DO concentration was $6.67 \mathrm{mg} \cdot \mathrm{L}^{-1}$, while for Perlidae the lowest concentration of this variable was $7.0 \mathrm{mg} \cdot \mathrm{L}^{-1}$. Additionally, mountain rivers are likely to maintain relatively high oxygen saturation due to their high velocity and turbulence. Consequently, these rivers have better aeration and less sedimentation of oxygen-consuming materials thus being more resistant to organic pollution [14]. Regarding Dissolved Oxygen, Connolly, et al. [58] mentioned that mayflies populations declined dramatically when the DO levels were less than $20 \%$ of saturation. Moreover, a finding in the highlands of Ecuador consistent with our analysis established that no EPT taxa were present in tributaries when the oxygen saturation was lower than $80 \%$ [13].

Flow velocity is another important variable that has been analyzed by some authors. In this research, the aforementioned variable is part of the two predictable models for Leptoceridae and Perlidae whereas it is not a factor for the Baetidae model. Interestingly, Holguin-Gonzalez, et al. [57] reported the flow velocity as a predictor of the presence of macroinvertebrates in Colombia. In the same way, Ríos-Touma, et al. [11] in their research, in the high altitude tropical streams in Ecuador, found that flow velocity had influence in abundance, in communities such as Leptoceridae. However, Ríos-Touma, et al. [11] reported that this variable is less important for macrobenthos with faster development times such as Baetidae, which is less susceptible to hydraulic disturbance. A similar finding in Zimbabwe for the Trichoptera order, showed a strong relation between their occurrence and abiotic parameters such as flow velocity and average depth [59].

The temperature variation between high altitudes despite short distances to reach them is considerable. In addition, the hourly and daily temperatures at one altitude fluctuate substantially in the tropical Andes Mountains [11]. Furthermore, due to lower water temperature, the solubility of 
oxygen increases leading to elevated DO concentrations in the water. At higher elevations, however, the atmospheric partial pressure of oxygen diminishes with ascension in altitude, countering the effects of lower temperature [14]. The aforementioned temperature is part of two GLMs (Baetidae and Perlidae) and it is negatively correlated with the possible presence of these two taxa. A similar correlation was found for the prediction of the EPT taxa in the tropical Andean region of Bolivia [12] or for the macrobenthos assemblage in California [60].

The significant variables of the three GLMs that were related to organic pollution were COD, $\mathrm{BOD}_{5}$ and fecal coliforms. The first variable was in relation to the possible presence of Baetidae and Leptoceridae, while $\mathrm{BOD}_{5}$ was only associated with the probable occurrence of Leptoceridae and fecal coliforms related to the possible existence of Baetidae and Perlidae. Outcomes were consistent with Jacobsen [14], who specified that the effect of organic pollution on the macrobenthos in Ecuadorian high land tributaries was the same as rivers at higher latitudes. In this way, Jacobsen [14] and Ríos-Touma, et al. [11] reported in their research in the Andes of Ecuador that Plecoptera, in which Perlidae originates, was present in pristine conditions and unpolluted places. With regard to Leptoceridae, the previously mentioned authors described that this family was present in only slightly polluted places. While, with regard to Baetidae, Jacobsen [14] expressed that these taxa were not found in severely polluted streams. Macrobenthos are known to be affected by organic pollution for two reasons: the first is dissolved oxygen reduction and the second is due to alteration of the substratum and loss of available food sources [61]. Furthermore, a study performed in the Itambi River, located in the northern Andes of Ecuador, evaluated the impact of organic pollution. The study concluded that the number of macroinvertebrate species was reduced when the concentration of $\mathrm{BOD}_{5}$ increased with a subsequent decrease in DO and vice versa [62]. In the samples subject of this research, it was found that when Perlidae were present the maximum COD and $\mathrm{BOD}_{5}$ were equal to $14 \mathrm{mg} \cdot \mathrm{L}^{-1}$ and $0.5 \mathrm{mg} \cdot \mathrm{L}^{-1}$ respectively. The relatively low concentration of $\mathrm{COD}$ and $\mathrm{BOD}_{5}$, could be the main reason these variables were not present in the Perlidae Model. In either case, when one of the three families was present, the maximum concentration of COD was equal to $46 \mathrm{mg} \cdot \mathrm{L}^{-1}$, an amount registered for Baetidae. For more sensitive taxa, lower values of COD were registered for their presence. These findings are in line for the EPT taxa, which are considered indicators of relatively clean water due to their sensitivity to pollution $[2,4,12]$.

Two other variables, color and $\mathrm{pH}$, had respective relationships to Baetidae or Leptoceridae. On the one hand, color had a negative correlation with the model to predict the probable presence of Baetidae. The range of this predictor, when these taxa were found, varied from 0 to 27 Hazen units (HU). The color in natural water consisted mainly of the generic humic and fulvic fraction of dissolved organics [63], and its intensity could be increased in direct relation to the amount of precipitation and runoff [64]. The humic substances are organic acids and their accumulation and dissolution in water are associated with a reduction of $\mathrm{pH}[47,65]$. The $\mathrm{pH}$ also had a negative correlation as a possible predictor of the presence of Leptoceridae, which was found when $\mathrm{pH}$ was between 6.33 and 8. Similar values (4.6 to 7.9) were found when Leptoceridae were present in research done in the high-altitude streams in Uganda [46]. In addition, the composition and abundance of macroinvertabrate taxa have been shown to have a relationship with $\mathrm{pH}$ [66] and subtle differences in this parameter may explain the differences in macrobenthos assemblages [65]. The potential of hydrogen has been used to predict the presence of some families of macrobenthos, such as Baetidae, Hydroptilidae and Simuliidae [38,46,67].

The application of the three GLMs to find the probable presence of the three families studied (i.e., Baetidae, Leptoceridae and Perlidae) is defined by the measured range of the predictors found in this research. Regarding this topic, some authors have written that the preferential conditions of a family varies from place to place, in connection with abiotic settings [12,38]. Hence, the three constructed models could not be simulated in different amplitude of the predictors that were evaluated in this investigation. 


\subsection{Model Performance}

Three GLMs for three different EPT taxa (i.e., Baetidae, Leptoceridae and Perlidae) were built in this study using a generalized linear model. GLMs have the advantage of directly establishing and reporting the relative importance of each variable in searching for the biotic integrity [68]. Furthermore, a stepwise discriminant procedure to select the most significant variables based on the AIC selection criteria applied in this research, has been shown to be effective in the prediction of species distribution [69]. However, the variables chosen for the developed models were not necessarily the only ones that were important. Variables that were not selected could be due to a correlation with another variable or with a set of variables [1], or that they were less important for the model than variables that were selected.

Because the data sample size (33 points) was relatively small ( $<100$ points) $[70,71]$, the binary data that represents their presence and absence was applied for the construction of the GLMs. With regard to small sample sizes, Stockwell and Peterson [71] concluded that the accuracy of samples of ten points was $90 \%$ and when the size increased to 50 points their accuracy was near maximal. In addition, logistic regression models that were applied to different small sample sizes showed a stable goodness-of-fit in their predictable capability [37,72]. Despite the fact that the basin is regulated and taking into account the samples were only taken in the rainy season, binary construction was applied for the model development. This kind of development based on one season gives the best results, however, it does not allow for insights in to seasonal variations related to the abundance of macrobenthos [38]. Moreover, the probability of the existence of taxa based on their presence or absence was estimated with a GLM with binomial adjustment, which is more suitable and often used for these types of predictions $[36,73,74]$.

The suitability of the developed models in the first instance is in the range in which the eight explanatory variables were measured (Figures A3 and A4). For Baetidae, the presence or absence of this taxa as a result of their GLM, could be inferred in lower or higher values of color and temperature. However, we do not recommend extrapolating for the possible presence of this family when the concentrations are greater than the measured range for the COD $\left(46 \mathrm{mg} \cdot \mathrm{L}^{-1}\right)$ and conductivity $\left(238 \mu \mathrm{S} \cdot \mathrm{cm}^{-1}\right)$. The presence or absence of Leptoceridae according to the developed GLM, could be extrapolated by flow velocity, conductivity, $\mathrm{COD}, \mathrm{BOD}_{5}$ and $\mathrm{pH}$. Nonetheless, we do not advise to infer the possible presence of this family when fecal coliforms are higher than the measured range $\left(1.7 \times 10^{5}\right.$ MPN.100 mL $\left.{ }^{-1}\right)$. Regarding the Perlidae model, the temperature and fecal coliforms could be extrapolated in smaller and greater measured values for determination of their presence or absence. However, this model must not be extrapolated without prior determination of the presence of this taxa in higher values of flow velocity $\left(1.30 \mathrm{~m} \cdot \mathrm{s}^{-1}\right)$ and conductivity $\left(177.9 \mu \mathrm{S} \cdot \mathrm{cm}^{-1}\right)$.

According to Mac Nally [75], the typical $R^{2}$ found in 100 cases analyzed was around $50 \%$ with $p>0.5$ and $R^{2}$ value diminished to $25 \%$, when only the significant variables were retained in the models. The author mentioned also specified that much simpler models with less variables produced typical $R^{2}$ around $30 \%$ with $p<0.001$.The goodness-of-fit of the three GLMs, which was also measured with the correlation coefficient adjusted $R^{2}$, has shown that the Leptoceridae model had the highest value $(67.6 \%)$, followed by the Baetidae (60\%) and the Perlidae (43.5\%) GLMs, a common adjustment range found in ecological models. When the accuracy of the model was assessed with an independent validation set, the adjusted $R^{2}$ was similar for both the Baetidae and the Leptoceridae (86\%), while for Perlidae it was the lowest with an analogous value that was obtained with the training data set. In the latter value, it is not clear why this was the lowest.

\section{Conclusions}

Three generalized linear models (GLMs) were built in order to understand the physicochemical water quality variables that determine the relation to the presence of three selected EPT taxa. Eight variables, identified during the stepwise selection procedure, showed a clear relation to the probable occurrence of the analyzed families. Each taxon had its own explanatory variables, of which 
conductivity was a unique common term between the GLMs of the three families. The fit of the GLMs was measured with the Akaike information criterion (AIC), the adjusted $R^{2}$, as well as, an independent validation data set. The adjusted $R^{2}$ varied from $43.5 \%$ to $67.6 \%$, values that are common for ecological models. Therefore, the GLMs could be used as tools to predict changes in the biological quality of the Machangara River.

Acknowledgments: This research was executed in the context of VLIR-UOS IUC Programme-University of Cuenca and the VLIR Ecuador Biodiversity Network project. The authors would also like to extend their gratitude to the Council of the Machangara River Basin for allowing the use of the field information collected from the Construction of the Integrated Management Plan of the Machangara Basin Project. Gert Everaert is supported by a post-doctoral fellowship from the Special Research Fund of Ghent University (BOF15/PDO/061) in Belgium.

Author Contributions: Ruben Jerves-Cobo was involved in sampling preparation, supported the sampling, analyzed the data and wrote the article. Xavier Iñiguez-Vela, Gonzalo Cordova-Vela prepared and performed the sampling campaign. Catalina Díaz-Granda helped to prepare and to support the sampling campaign. Gert Everaert, Felipe Cisneros, Ingmar Nopens and Peter L. M. Goethals were involved in data analysis and writing the article.

Conflicts of Interest: The authors declare no conflict of interest.

\section{Abbreviations}

The following abbreviations were used in this manuscript:

$\begin{array}{ll}\text { AIC } & \text { Akaike information criterion } \\ \text { ANNs } & \text { artificial neural networks } \\ \text { BBNs } & \text { Bayesian belief networks } \\ \text { BMWP } & \text { Biological Monitoring Working Party } \\ \text { BMWP-Col } & \text { Biological Monitoring Working Party adapted to Colombia } \\ \text { BOD } 5 & \text { Biochemical Oxygen Demand 5 d } \\ \text { color } & \text { True color } \\ \text { CSOs } & \text { combined sewer overflows } \\ \text { COD } & \text { chemical oxygen demand } \\ \text { CTs } & \text { classification trees } \\ \text { DO } & \text { Dissolved Oxygen } \\ \text { EPT } & \text { Ephemeroptera-Plecoptera-Trichoptera } \\ \text { GAs } & \text { genetic algorithms } \\ \text { GLM } & \text { generalized linear models } \\ \text { LRs } & \text { logistic regressions } \\ \text { MASL } & \text { meters above sea level } \\ \text { MPN.100 mL } & \text { most probable number per } 100 \text { milliliters } \\ \text { RTs } & \text { regression trees } \\ \text { TS } & \text { tolerant score } \\ \text { TSol } & \text { Total Solids } \\ \text { SVMs } & \text { support-vector machines } \\ \text { SWO } & \text { surface water outfalls }\end{array}$




\section{Appendix A}

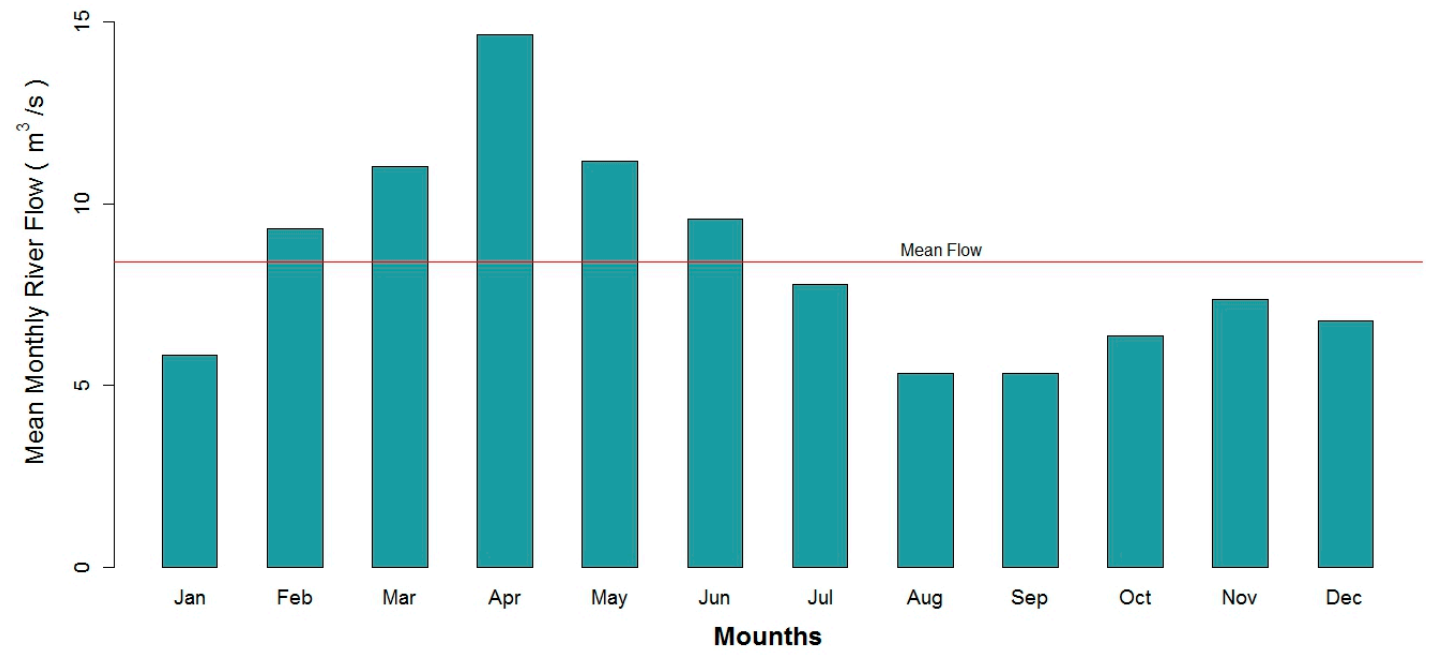

Figure A1. Histogram Machangara River before discharging into Tomebamba River (1964-2010).

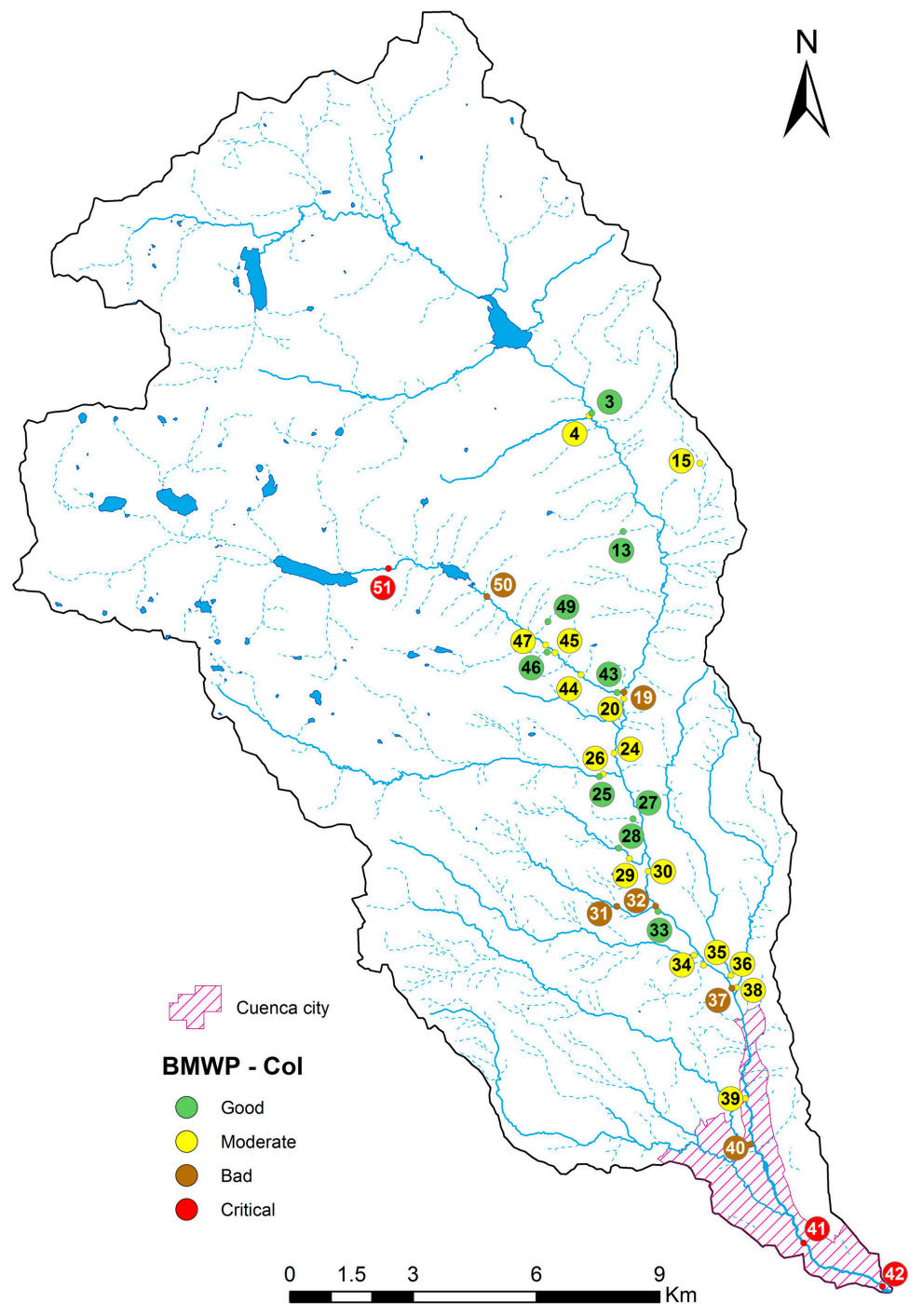

Figure A2. Location of sites selected for model simulation with BMWP-Col qualification. 
A

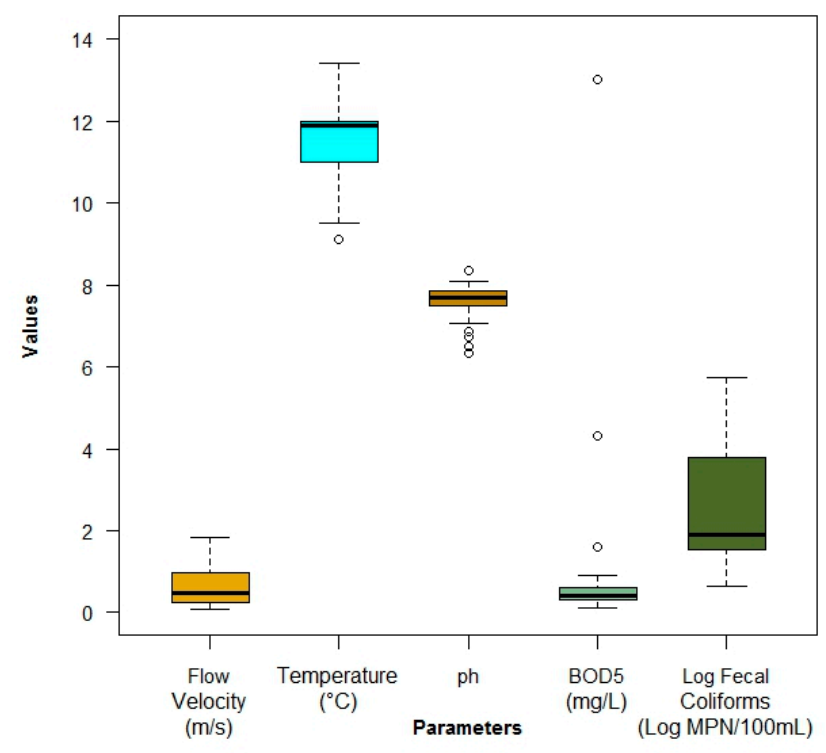

B

C
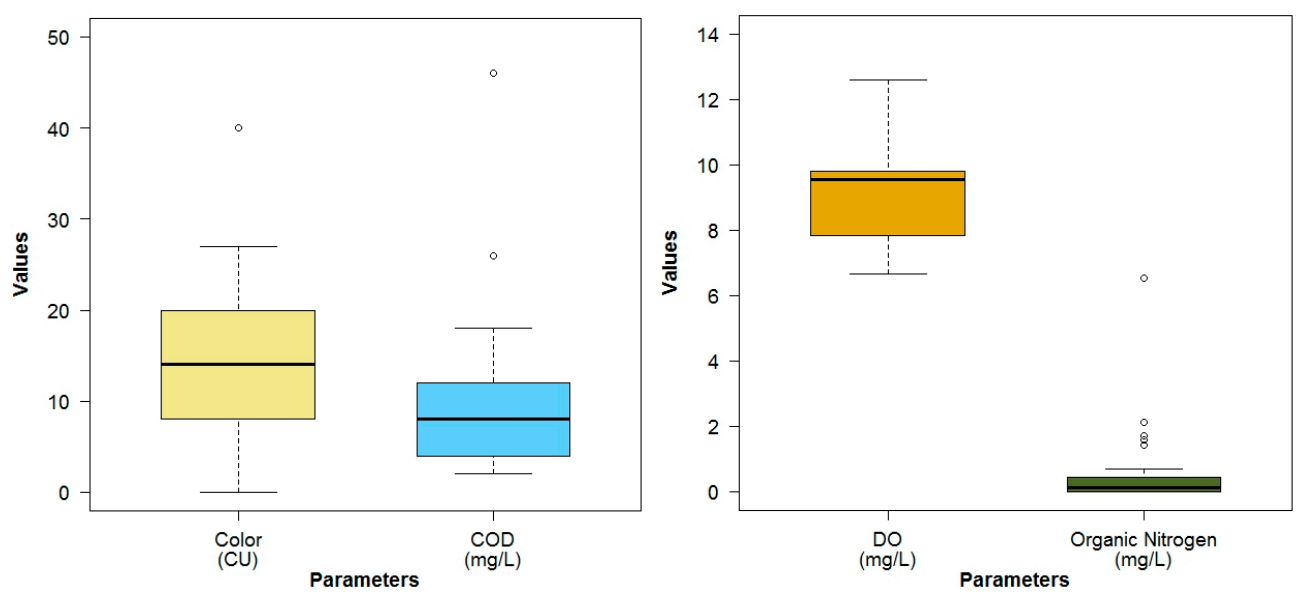

Figure A3. Boxplots of the physicochemical parameters: (A) Flow Velocity, Water Temperature, $\mathrm{pH}$, $\mathrm{BOD}_{5}$, Log Fecal Coliforms; (B) True color and COD; (C) Dissolved Oxygen (DO) and Organic Nitrogen.

A

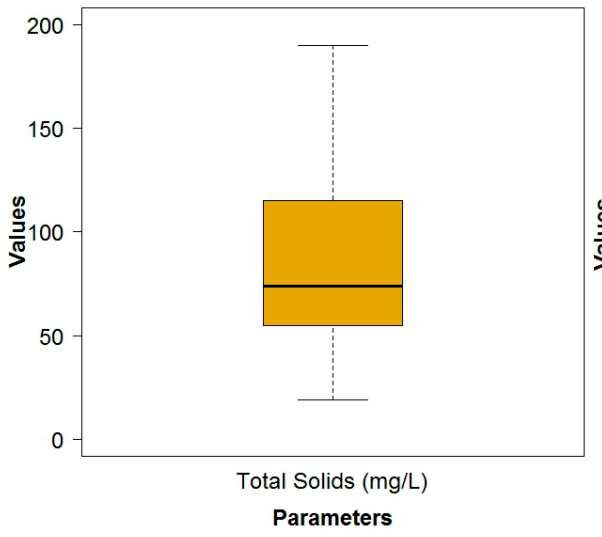

B

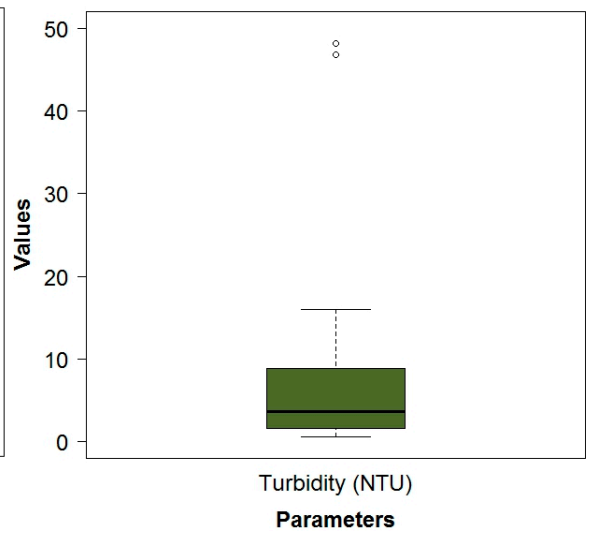

Figure A4. Cont. 

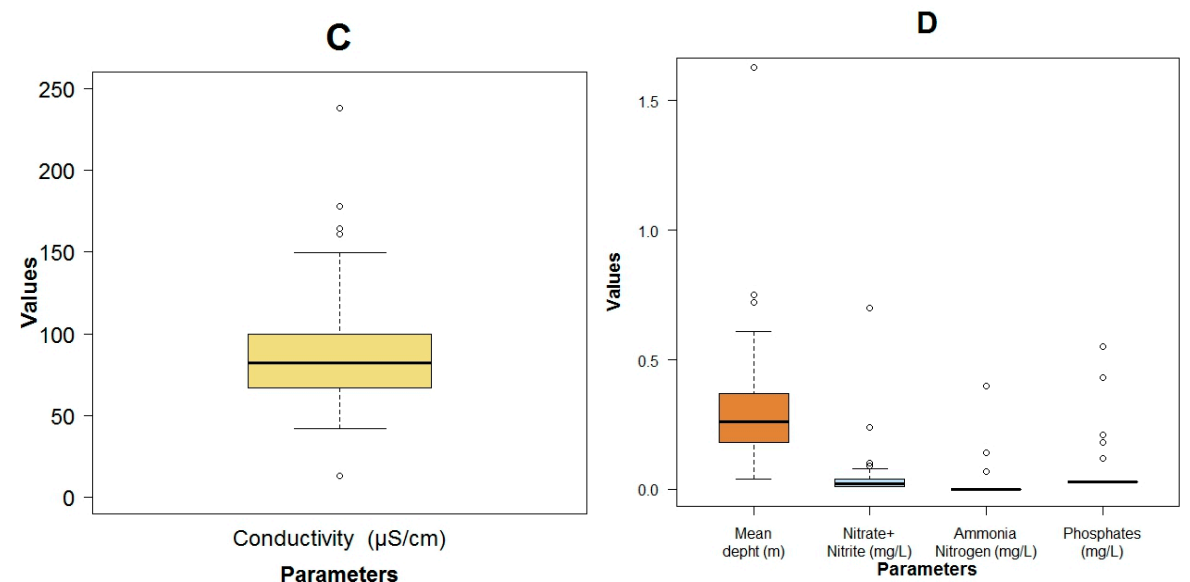

Figure A4. Boxplots of the physicochemical parameters: (A) Total Solids; (B) Turbidity; (C) Conductivity; (D) Mean depth, Nitrate + Nitrite, Ammonia Nitrogen and Phosphates.

A

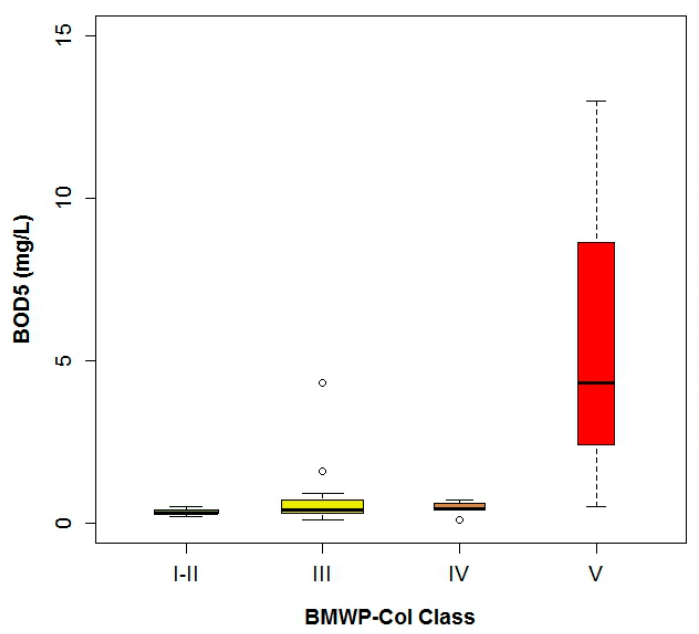

C

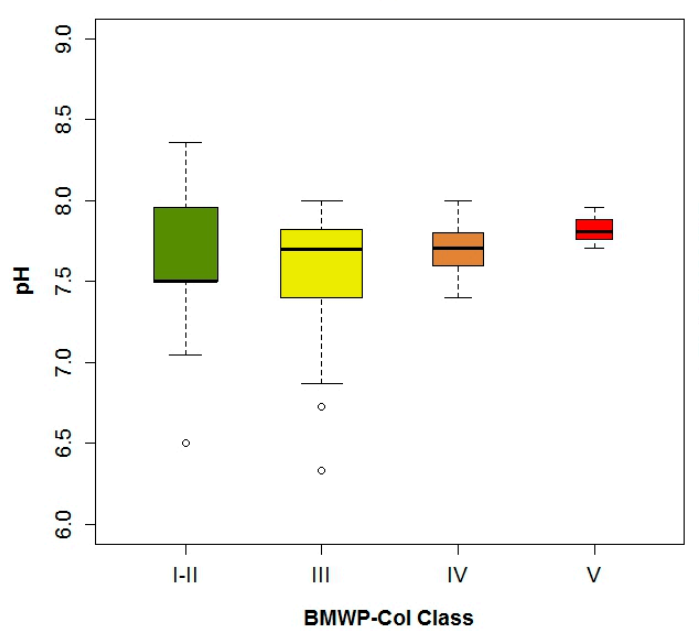

B

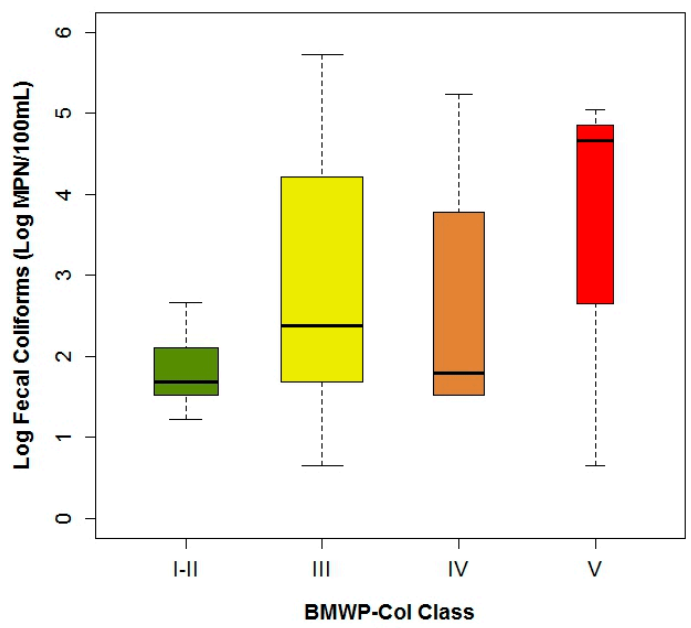

D

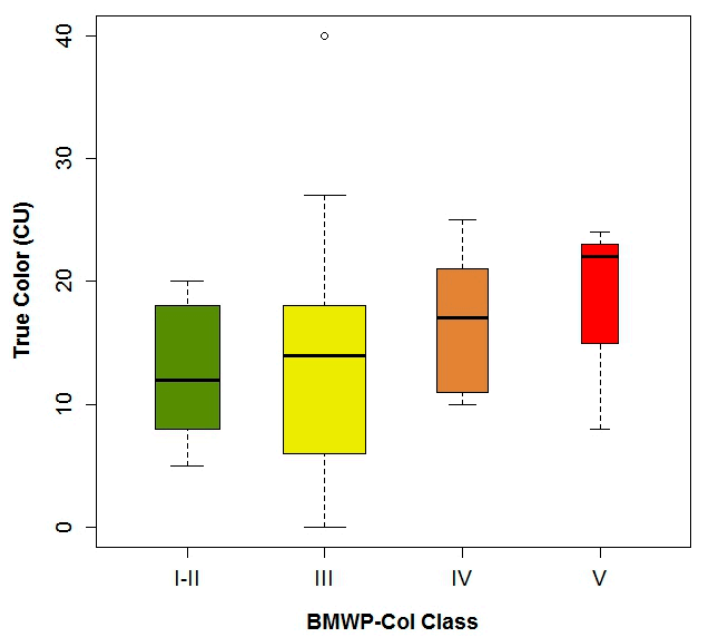

Figure A5. Boxplots of the BMWP-Col with the others explanatory variables of the three models: $\mathrm{BOD}_{5}(\mathbf{A})$; Log fecal coliforms (B); $\mathrm{pH}(\mathbf{C})$ and color (D). 
A

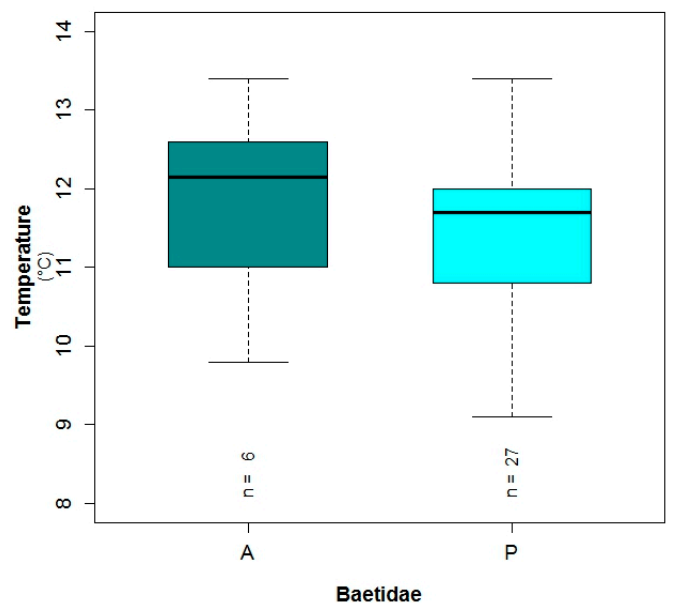

C

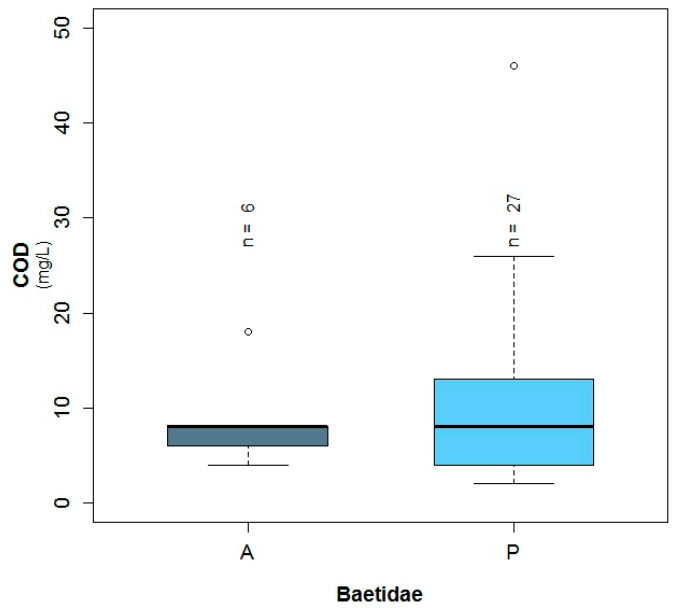

B

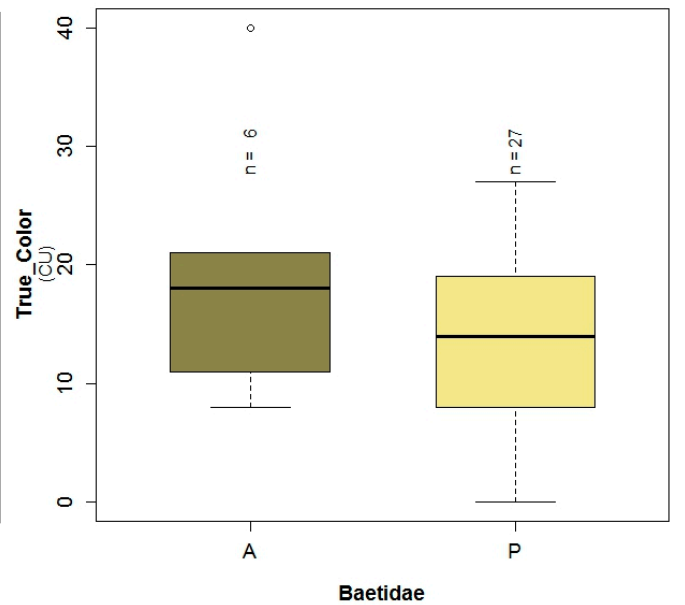

D

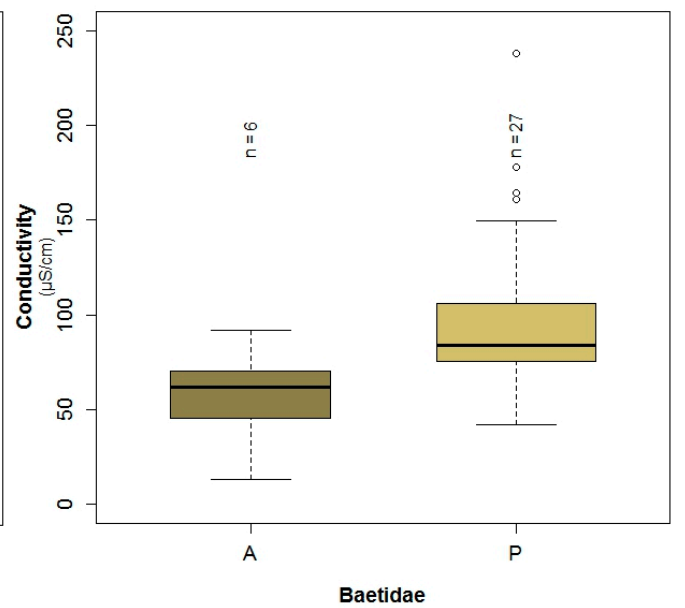

Figure A6. Boxplots showing the presence or absence of Baetidae with its explanatory variables: (A) temperature; (B) color; (C) COD and (D) conductivity.

A

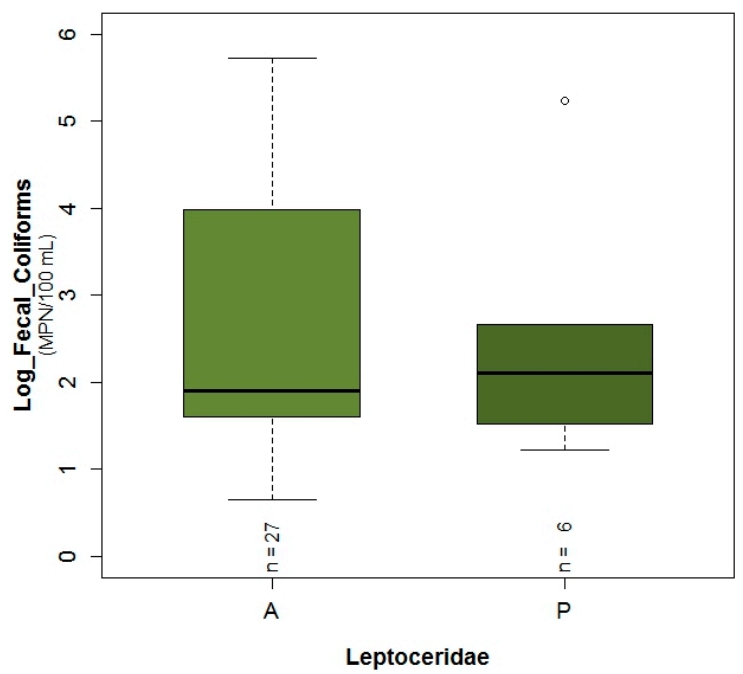

B

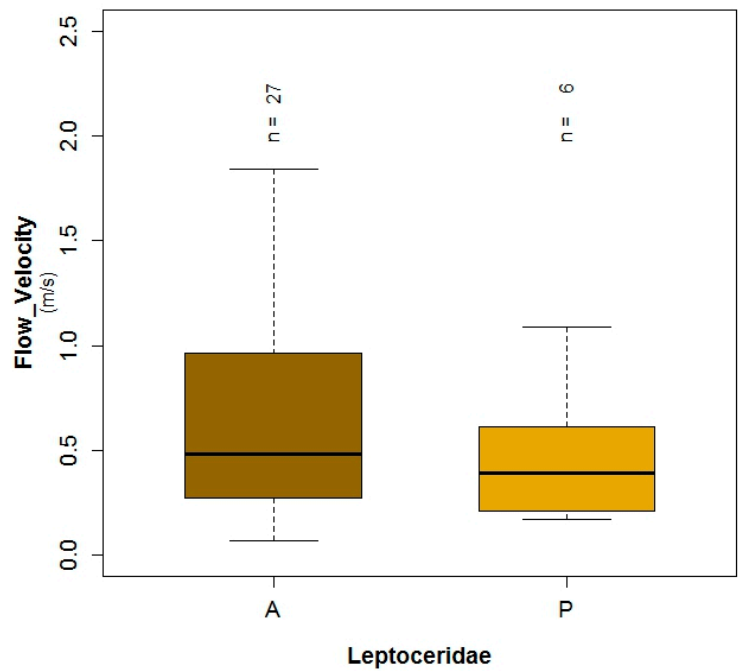

Figure A7. Cont. 
C

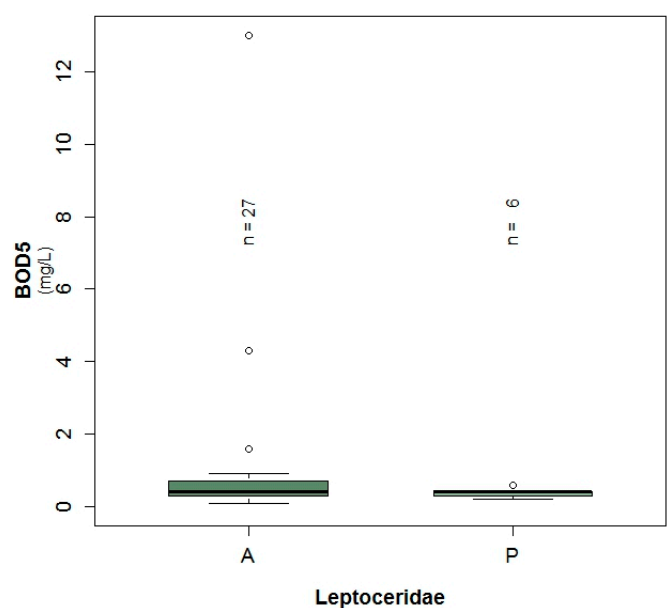

E

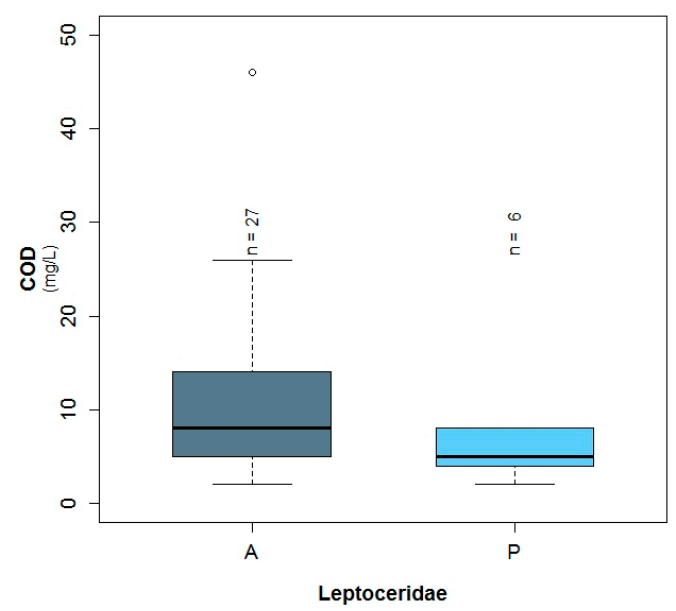

D

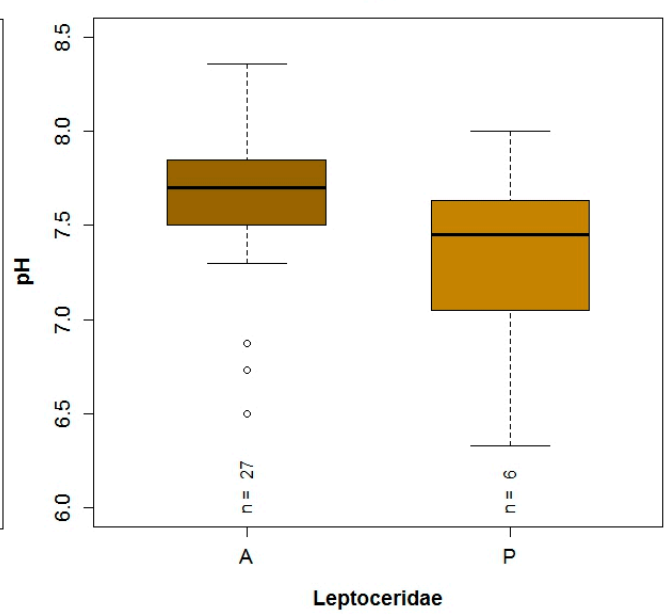

F

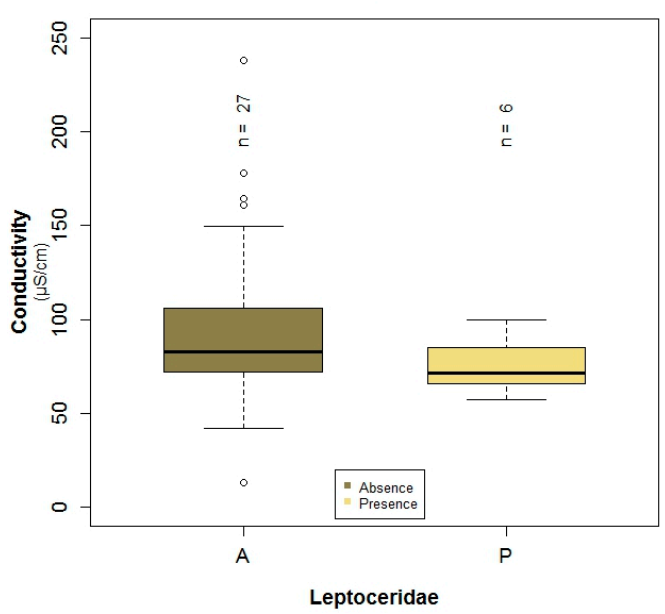

Figure A7. Boxplots showing the presence or absence of Leptoceridae with its explanatory variables (A) fecal coliforms expressed in log scale; (B) flow velocity; (C) BOD $_{5}$; (D) $\mathrm{pH}$; (E) COD and (F) conductivity.

A

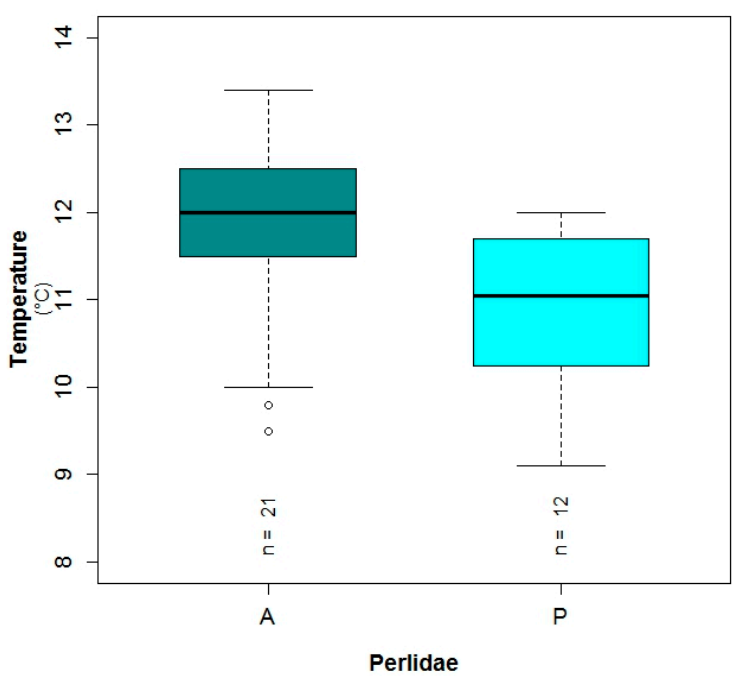

B

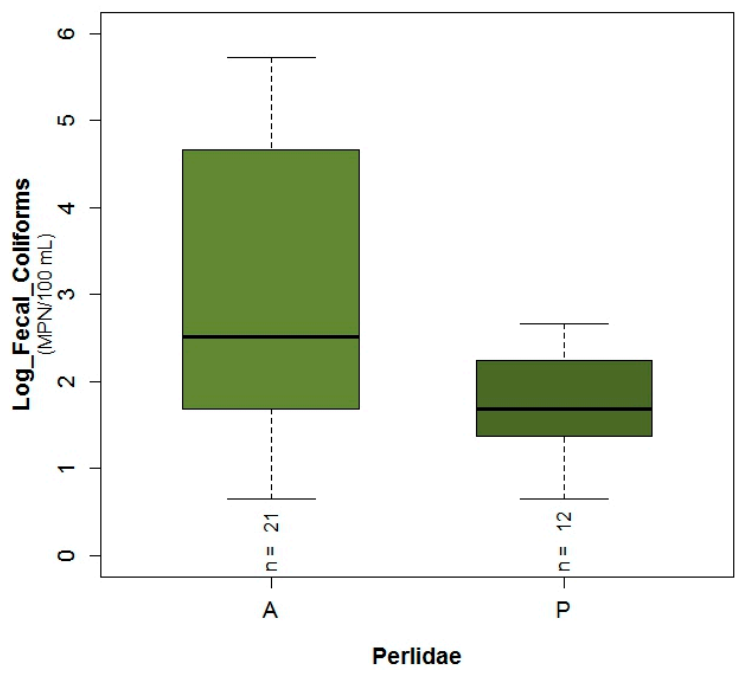

Figure A8. Cont. 
C

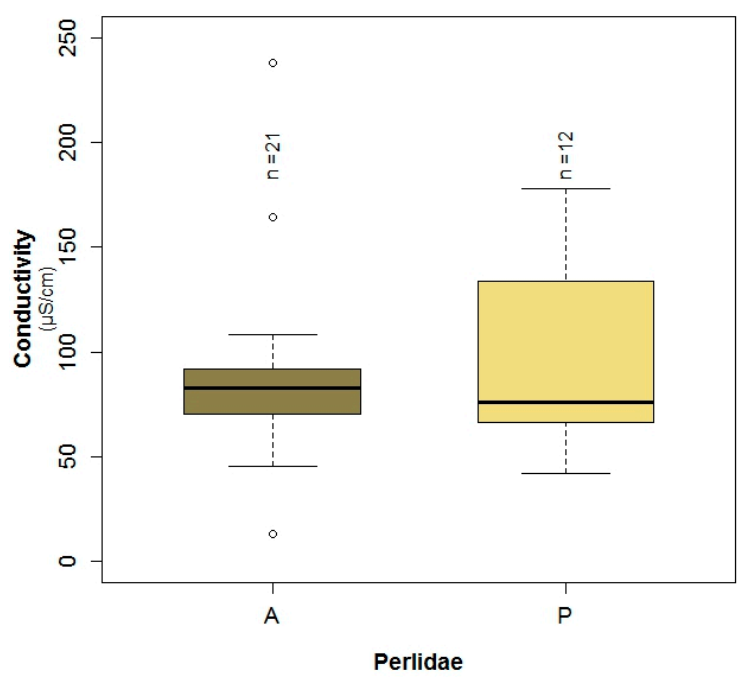

D

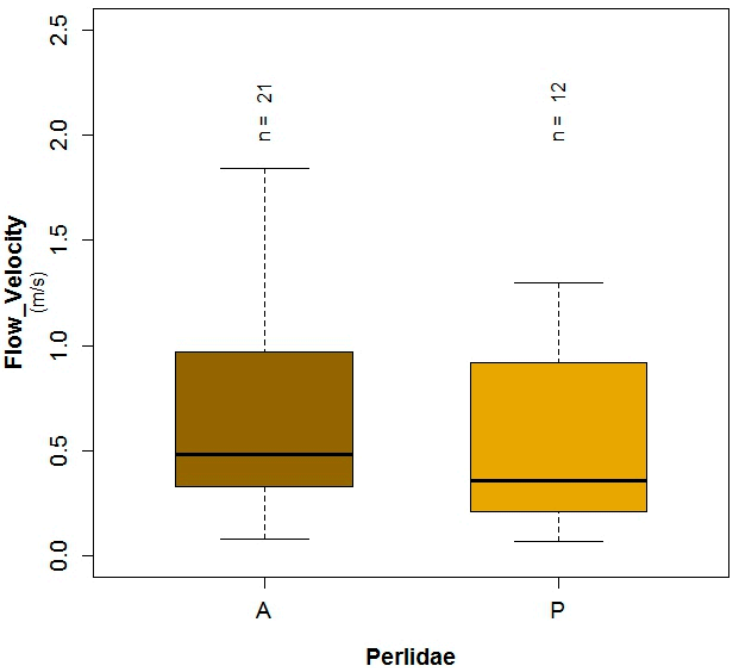

Figure A8. Boxplots showing the presence or absence of Perlidae with its explanatory variables (A) temperature; (B) fecal coliforms expressed in log scale; (C) conductivity; (D) flow velocity.

Table A1. Spearman correlation $p$-values of the explanatory variable used to construct the generalized linear models (GLMs).

\begin{tabular}{ccccccccc}
\hline Explanatory Variable & BOD $_{5}$ & COD & Conductivity & $\begin{array}{c}\text { Flow } \\
\text { Velocity }\end{array}$ & $\begin{array}{c}\text { Log Fecal } \\
\text { Coliforms }\end{array}$ & pH & $\begin{array}{c}\text { True Color } \\
\text { (Color) }\end{array}$ & $\begin{array}{c}\text { Water } \\
\text { Temperature }\end{array}$ \\
\hline BOD $_{5}$ & & & & & & & & \\
COD & $<0.001$ & & & & & & & \\
Conductivity & 0.726 & 0.956 & & & & & & \\
Flow velocity & 0.531 & 0.151 & 0.097 & & & & & \\
Log fecal coliforms & $<0.001$ & 0.009 & 0.04 & 0.298 & & & \\
pH & 0.231 & 0.404 & 0.375 & 0.499 & 0.021 & & & \\
True color (color) & 0.002 & $<0.001$ & 0.08 & 0.104 & 0.063 & 0.663 & & \\
Water temperature & 0.005 & 0.267 & 0.087 & 0.881 & 0.144 & 0.996 & 0.909 \\
\hline
\end{tabular}

Table A2. Regression parameters: Standard Error and $z$ value of the models for predicting the presence of Baetidae, Leptoceridae and Perlidae.

\begin{tabular}{ccccccc}
\hline \multirow{2}{*}{ Explanatory Variable } & \multicolumn{2}{c}{ Baetidae } & \multicolumn{2}{c}{ Leptoceridae } & \multicolumn{2}{c}{ Perlidae } \\
\cline { 2 - 7 } & Std. Error & $z$ Value & Std. Error & $z$ Value & Std. Error & $z$ Value \\
\hline & 16.86 & 1.60 & 21.99 & 2.30 & 6.53 & 2.17 \\
BOD $_{5}$ & & & 6.59 & -1.88 & & \\
COD & 0.46 & 1.63 & 0.57 & -1.95 & & \\
Conductivity & 0.06 & 2.06 & 0.04 & -1.85 & 0.02 & 2.10 \\
Flow velocity & & & 5.80 & -2.11 & 1.67 & 1.39 \\
Log fecal coliforms & & & 3.07 & 2.09 & 0.83 & -2.28 \\
pH & 1.55 & -1.84 & 2.42 & -2.19 & & 0.64 \\
Temperature & 0.25 & -1.66 & & & & -2.24 \\
True color (color) & & & & & & \\
\hline
\end{tabular}


Table A3. Process of model development for Baetidae: $p$-values, AIC and adjusted $R^{2}$.

\begin{tabular}{|c|c|c|c|c|c|c|c|c|c|c|c|c|c|c|c|c|c|c|c|}
\hline \multirow[b]{2}{*}{ Model } & \multirow[b]{2}{*}{ (Intercept) } & \multicolumn{16}{|c|}{$p$-Value } & \multirow[b]{2}{*}{ AIC } & \multirow{2}{*}{$\begin{array}{l}R^{2} \\
(\%)\end{array}$} \\
\hline & & $\begin{array}{c}\text { Flow } \\
\text { Velocity }\end{array}$ & $\mathrm{BOD}_{5}$ & Turbidity & $\begin{array}{l}\text { Mean } \\
\text { Depth }\end{array}$ & Temperature & $\mathrm{pH}$ & DO & Color & Conductivity & COD & $\begin{array}{l}\text { Nitrate. } \\
\text { Nitrite }\end{array}$ & $\begin{array}{c}\text { Ammonia } \\
\text { Nitrogen }\end{array}$ & $\begin{array}{c}\text { Organic } \\
\text { Nitrogen }\end{array}$ & $\begin{array}{c}\text { Total } \\
\text { Solids } \\
\end{array}$ & $\begin{array}{l}\text { Log Fecal } \\
\text { Coliforms }\end{array}$ & Phosphates & & \\
\hline $\mathrm{m} 1301$ & 1.00 & 1.00 & 1.00 & 1.00 & 1.00 & 1.00 & 1.00 & 1.00 & 1.00 & 1.00 & 1.00 & 1.00 & 1.00 & 1.00 & 1.00 & 1.00 & 1.00 & 40 & 100 \\
\hline m1302 & 1.00 & 1.00 & 1.00 & 1.00 & 1.00 & 1.00 & 1.00 & 1.00 & 1.00 & 1.00 & 1.00 & 1.00 & 1.00 & 1.00 & 1.00 & 1.00 & 1.00 & 38 & 100 \\
\hline m1303 & 1.00 & 1.00 & 1.00 & 1.00 & 1.00 & 1.00 & 1.00 & 1.00 & 1.00 & 1.00 & 1.00 & 1.00 & 1.00 & 1.00 & 1.00 & 1.00 & - & 36 & 100 \\
\hline m1304 & 1.00 & 1.00 & 1.00 & 1.00 & 1.00 & 1.00 & 1.00 & 1.00 & 1.00 & 1.00 & 1.00 & & 1.00 & 1.00 & 1.00 & 1.00 & - & 34 & 100 \\
\hline m1305 & 1.00 & 1.00 & 1.00 & 1.00 & 1.00 & 1.00 & 1.00 & 1.00 & 1.00 & 1.00 & 1.00 & - & 1.00 & 1.00 & 1.00 & 1.00 & - & 32 & 100 \\
\hline $\mathrm{m} 1306$ & 1.00 & 1.00 & 1.00 & 1.00 & 1.00 & 1.00 & 1.00 & 1.00 & 1.00 & 1.00 & 1.00 & - & 1.00 & 1.00 & 1.00 & 1.00 & - & 30 & 100 \\
\hline m1307 & 1.00 & 1.00 & 1.00 & 1.00 & - & 1.00 & 1.00 & 1.00 & 1.00 & 1.00 & 1.00 & - & 1.00 & 1.00 & 1.00 & 1.00 & - & 28 & 100 \\
\hline m1308 & 1.00 & 1.00 & 1.00 & 1.00 & - & 1.00 & 1.00 & 1.00 & 1.00 & 1.00 & 1.00 & - & - & 1.00 & 1.00 & 1.00 & - & 26 & 100 \\
\hline m1309 & 1.00 & - & 1.00 & 1.00 & - & 1.00 & 1.00 & 1.00 & 1.00 & 1.00 & 1.00 & - & - & 1.00 & 1.00 & 1.00 & - & 24 & 100 \\
\hline m1310 & 1.00 & - & 1.00 & 1.00 & - & 1.00 & - & 1.00 & 1.00 & 1.00 & 1.00 & - & - & 1.00 & 1.00 & 1.00 & - & 22 & 100 \\
\hline m1311 & 1.00 & - & 1.00 & 1.00 & - & 1.00 & - & 1.00 & 1.00 & 1.00 & 1.00 & - & - & - & 1.00 & 1.00 & - & 20 & 100 \\
\hline m1312 & 0.97 & - & 0.98 & 0.97 & - & 0.97 & - & 0.97 & 0.97 & 0.97 & 0.97 & - & - & - & 0.97 & - & - & 18 & 100 \\
\hline m1313 & 0.65 & - & - & 0.74 & - & 0.65 & - & 0.67 & 0.70 & 0.97 & 0.70 & - & - & - & 0.70 & - & - & 24 & 75 \\
\hline m1314 & 0.31 & - & - & 0.41 & - & 0.34 & - & 0.31 & 0.38 & - & 0.42 & - & - & - & 0.33 & - & - & 22 & 75 \\
\hline m1315 & 0.08 & - & - & 0.18 & - & 0.10 & - & 0.08 & 0.12 & - & - & - & - & - & 0.34 & - & - & 26 & 56 \\
\hline m1316 & 0.04 & - & - & 0.09 & - & 0.08 & - & 0.06 & 0.05 & - & - & - & - & - & - & - & - & 25 & 52 \\
\hline m1317 & 0.04 & - & - & - & - & 0.11 & - & 0.06 & 0.06 & - & - & - & - & - & - & - & - & 31 & 26 \\
\hline m1318 & 0.04 & - & - & - & - & - & - & 0.16 & 0.11 & - & - & - & - & - & - & - & - & 33 & 15 \\
\hline m1319 & 0.09 & - & - & - & - & - & - & 0.20 & 0.00 & - & - & - & - & - & - & - & - & 34 & 6 \\
\hline m1320 & 0.08 & - & - & 0.26 & - & 0.08 & - & 0.14 & 0.25 & 0.27 & - & - & - & - & - & - & - & 25 & 58 \\
\hline m1321 & 0.05 & - & - & 0.08 & - & 0.07 & - & 0.10 & 0.07 & - & 0.30 & - & - & - & - & - & - & 25 & 57 \\
\hline m1322 & 0.07 & - & 0.85 & 0.12 & - & 0.14 & - & 0.07 & 0.07 & - & - & - & - & - & - & - & - & 27 & 53 \\
\hline m1323 & 0.21 & - & - & 0.20 & - & 0.06 & 0.39 & 0.13 & 0.08 & - & - & - & - & - & - & - & - & 26 & 55 \\
\hline m1324 & 0.98 & - & - & 0.98 & - & 0.98 & - & 0.98 & 0.98 & - & - & - & - & - & - & 0.98 & - & 12 & 100 \\
\hline m1325 & 0.99 & - & - & 0.11 & - & 0.08 & - & 0.08 & 0.06 & - & - & - & - & - & - & - & 1.00 & 27 & 54 \\
\hline m1326 & 0.05 & - & - & 0.10 & - & 0.09 & - & 0.06 & 0.05 & - & - & 1.0 & - & - & - & - & - & 27 & 52 \\
\hline m1327 & 0.05 & - & - & 0.10 & - & $\begin{array}{l}0.09 \\
\end{array}$ & - & 0.06 & 0.05 & - & - & 1.0 & 1.00 & - & - & - & - & 27 & 53 \\
\hline m1328 & 0.05 & - & - & 0.10 & - & 0.09 & - & 0.06 & 0.06 & - & - & 0.83 & - & - & - & - & - & 27 & 53 \\
\hline m1329 & 0.09 & - & - & 0.30 & - & 0.11 & - & 0.11 & 0.26 & - & - & - & - & 0.33 & - & - & - & 25 & 58 \\
\hline m1330 & 0.08 & - & - & 0.18 & - & 0.10 & - & 0.08 & 0.12 & - & - & - & - & - & 0.34 & - & - & 26 & 56 \\
\hline m1331 & 1.00 & - & - & 1.00 & - & 1.00 & - & 1.00 & 1.00 & - & - & - & - & - & - & - & - & 12 & 100 \\
\hline $\mathrm{m} 1332$ & 0.99 & - & - & 0.11 & - & 0.08 & - & 0.08 & 0.06 & - & - & - & - & - & - & - & - & 27 & 54 \\
\hline m1333 & 0.05 & - & - & 0.07 & 0.23 & 0.07 & - & 0.08 & 0.07 & - & - & - & - & - & - & - & - & 25 & 59 \\
\hline m1334 & 0.15 & 0.12 & - & 0.13 & - & 0.17 & - & 0.15 & 0.07 & - & - & - & - & - & - & - & - & 21 & 72 \\
\hline m1335 & 0.12 & 0.29 & - & 0.21 & - & 0.00 & - & 0.18 & 0.07 & - & - & - & - & - & - & - & - & 30 & 38 \\
\hline m1336 & 0.07 & - & - & 0.15 & - & 0.00 & - & 0.17 & 0.07 & - & - & - & - & - & - & - & - & 29 & 33 \\
\hline m1337 & 1.00 & 1.00 & - & 1.00 & 1.00 & 1.00 & 1.00 & 1.00 & 1.00 & 1.00 & 1.00 & - & - & 1.00 & 1.00 & - & - & 24 & 100 \\
\hline m1338 & 1.00 & 1.00 & - & 1.00 & - & 1.00 & 1.00 & 1.00 & 1.00 & 1.00 & 1.00 & - & - & 1.00 & 1.00 & - & - & 22 & 100 \\
\hline m1339 & 1.00 & 1.00 & - & 1.00 & - & 1.00 & - & 1.00 & 1.00 & 1.00 & 1.00 & - & - & 1.00 & 1.00 & - & - & 20 & 100 \\
\hline m1340 & 0.99 & - & - & 0.99 & - & 0.99 & - & 0.99 & 0.99 & 0.99 & 0.99 & - & - & 0.99 & 1.00 & - & - & 18 & 100 \\
\hline m1341 & 0.99 & - & - & 0.99 & - & 0.99 & - & 0.99 & 0.99 & 0.99 & 0.99 & - & - & 0.99 & - & - & - & 16 & 100 \\
\hline $\mathrm{m} 1342$ & 0.10 & - & - & 0.35 & - & 0.12 & - & 0.40 & 0.17 & 0.17 & 0.31 & - & - & - & - & - & - & 24 & 67 \\
\hline m1343 & 0.14 & - & - & 0.36 & - & 0.12 & - & - & 0.14 & 0.09 & 0.20 & - & - & - & - & - & - & 23 & 65 \\
\hline m1344 & 0.11 & - & - & - & - & 0.07 & - & - & 0.10 & 0.04 & 0.10 & - & - & - & - & - & - & 22 & 60 \\
\hline
\end{tabular}


Table A4. Process of model development for Leptoceridae: $p$-values, AIC and adjusted $R^{2}$.

\begin{tabular}{|c|c|c|c|c|c|c|c|c|c|c|c|c|c|c|c|c|c|c|c|}
\hline \multirow[b]{2}{*}{ Model } & \multirow{2}{*}{ (Intercept) } & \multicolumn{16}{|c|}{$p$-Value } & \multirow[b]{2}{*}{ AIC } & \multirow{2}{*}{$\begin{array}{l}R^{2} \\
(\%)\end{array}$} \\
\hline & & $\begin{array}{c}\text { Flow } \\
\text { Velocity }\end{array}$ & $\mathrm{BOD}_{5}$ & Turbidity & $\begin{array}{l}\text { Mean } \\
\text { Depth }\end{array}$ & Temperature & $\mathrm{pH}$ & DO & Color & Conductivity & COD & $\begin{array}{l}\text { Nitrate. } \\
\text { Nitrite }\end{array}$ & $\begin{array}{l}\text { Ammonia } \\
\text { Nitrogen }\end{array}$ & $\begin{array}{c}\text { Organic } \\
\text { Nitrogen }\end{array}$ & $\begin{array}{c}\text { Total } \\
\text { Solids }\end{array}$ & $\begin{array}{l}\text { Log Fecal } \\
\text { Coliforms }\end{array}$ & Phosphates & & \\
\hline $\mathrm{m} 15$ & 0.69 & - & - & - & 0.05 & - & - & - & - & 0.80 & - & 0.11 & - & 0.50 & - & 0.11 & - & 45 & 25 \\
\hline $\mathrm{m} 150$ & 0.82 & - & - & - & 0.05 & - & - & - & - & - & - & 0.11 & - & - & - & 0.11 & - & 37 & 24 \\
\hline m152 & 0.30 & - & - & - & 0.07 & - & - & - & - & - & - & 0.26 & - & - & - & - & - & 38 & 16 \\
\hline m153 & 0.86 & - & - & - & 0.13 & - & - & - & - & - & - & - & - & - & - & 0.65 & - & 41 & 10 \\
\hline $\mathrm{m} 154$ & 0.86 & - & - & - & 0.14 & - & - & - & - & - & - & - & - & - & - & - & - & 39 & 9 \\
\hline m155 & 0.51 & 0.12 & - & - & 0.15 & - & - & - & - & - & - & 0.07 & - & - & - & 0.07 & - & 36 & 32 \\
\hline m156 & 0.88 & 0.04 & - & - & - & - & - & - & - & - & - & 0.11 & - & - & - & 0.08 & - & 38 & 23 \\
\hline m157 & 0.63 & 0.17 & - & - & - & - & - & - & - & - & - & - & - & - & - & 0.66 & - & 42 & 6 \\
\hline $\mathrm{m} 158$ & 0.52 & 0.04 & 0.10 & - & - & - & - & - & - & - & - & 0.12 & - & - & - & 0.03 & - & 34 & 38 \\
\hline m159 & 0.89 & 0.12 & 0.07 & - & - & - & - & - & - & - & - & - & - & - & - & 0.04 & - & 37 & 26 \\
\hline m1590 & 1.00 & 0.24 & 0.10 & - & 0.69 & - & - & - & - & - & - & - & - & - & - & 0.05 & - & 39 & 26 \\
\hline m1591 & 0.93 & 0.10 & 0.06 & 0.19 & - & - & - & - & - & - & - & - & - & - & - & 0.02 & - & 36 & 32 \\
\hline m1592 & 1.00 & 0.07 & 0.22 & 0.19 & - & - & - & - & - & - & - & - & - & - & - & 0.03 & - & 37 & 36 \\
\hline m1593 & 0.63 & 0.08 & 0.05 & 0.26 & - & - & - & - & - & 0.55 & - & - & - & - & - & 0.02 & - & 38 & 33 \\
\hline m1594 & 0.85 & 0.10 & 0.06 & 0.20 & - & - & - & 0.87 & - & - & - & - & - & - & - & 0.03 & - & 38 & 32 \\
\hline m1595 & 0.95 & 0.11 & 0.07 & 0.20 & - & 0.97 & - & - & - & - & - & - & - & - & - & 0.02 & - & 38 & 32 \\
\hline m1596 & 0.71 & 0.10 & 0.05 & 0.25 & - & - & - & - & - & - & - & - & - & - & 0.63 & 0.02 & - & 38 & 32 \\
\hline m1597 & 0.17 & 0.08 & 0.06 & 0.48 & - & - & 0.17 & - & - & - & - & - & - & - & - & 0.02 & - & 36 & 38 \\
\hline m1598 & 0.08 & 0.07 & 0.06 & - & - & - & 0.07 & - & - & - & - & - & - & - & - & 0.03 & - & 35 & 36 \\
\hline m1599 & 0.04 & 0.05 & 0.15 & - & - & - & 0.04 & - & - & - & 0.11 & - & - & - & - & 0.02 & - & 32 & 48 \\
\hline m1580 & 0.05 & 0.12 & - & - & - & - & 0.06 & - & - & - & 0.03 & - & - & - & - & 0.04 & - & 35 & 36 \\
\hline m1581 & 0.13 & - & - & - & - & - & 0.12 & - & - & - & 0.03 & - & - & - & - & 0.05 & - & 36 & 28 \\
\hline m1582 & 0.75 & - & - & - & - & - & - & - & - & - & 0.04 & - & - & - & - & 0.09 & - & 37 & 20 \\
\hline m1583 & 0.04 & 0.09 & 0.16 & - & 0.60 & - & 0.04 & - & - & - & 0.10 & - & - & - & - & 0.02 & - & 34 & 49 \\
\hline m1584 & 0.02 & 0.03 & 0.06 & - & - & - & 0.03 & - & - & 0.06 & 0.05 & - & - & - & - & 0.04 & - & 27 & 68 \\
\hline m1585 & 0.07 & 0.04 & 0.05 & 0.57 & - & - & 0.09 & - & - & 0.07 & 0.11 & - & - & - & - & 0.04 & - & 28 & 69 \\
\hline m1586 & 0.04 & 0.03 & 0.07 & - & - & - & 0.05 & - & - & 0.09 & 0.09 & 0.90 & - & - & - & 0.05 & - & 29 & 68 \\
\hline m1575 & 0.02 & 0.03 & 0.07 & - & 0.43 & - & 0.03 & - & - & 0.08 & 0.09 & - & - & - & - & 0.05 & - & 28 & 70 \\
\hline m1587 & 0.04 & 0.12 & 0.13 & - & - & 0.63 & 0.05 & - & - & 0.15 & 0.08 & - & - & - & - & 0.10 & - & 28 & 68 \\
\hline m1588 & 0.02 & 0.03 & 0.05 & - & - & - & 0.12 & 0.61 & - & 0.06 & 0.10 & - & - & - & - & 0.03 & - & 28 & 68 \\
\hline m1589 & 0.97 & 0.05 & 0.20 & - & - & - & 0.04 & - & - & 0.07 & 0.07 & - & - & - & - & 0.05 & - & 28 & 69 \\
\hline m1570 & 0.06 & 0.06 & 0.08 & - & - & - & 0.07 & - & - & 0.09 & 0.12 & - & - & - & 0.36 & 0.07 & - & 27 & 71 \\
\hline m1571 & 0.03 & 0.04 & 0.08 & - & - & - & 0.04 & - & 0.45 & 0.07 & 0.09 & - & - & - & - & 0.04 & - & 29 & 69 \\
\hline m1572 & 0.03 & 0.04 & 0.16 & - & - & - & 0.04 & - & - & 0.06 & 0.06 & - & 1.00 & - & - & 0.04 & - & 28 & 68 \\
\hline m1573 & 0.04 & 0.04 & 0.09 & - & - & - & 0.05 & - & - & 0.10 & 0.09 & 0.75 & - & - & - & 0.05 & - & 28 & 68 \\
\hline m1574 & 0.97 & 0.05 & 0.20 & - & - & - & 0.04 & - & - & 0.07 & 0.07 & - & - & - & - & 0.05 & 1.00 & 28 & 69 \\
\hline
\end{tabular}


Table A5. Process of model development for Perlidae: $p$-values, AIC and adjusted $R^{2}$.

\begin{tabular}{|c|c|c|c|c|c|c|c|c|c|c|c|c|c|c|c|c|c|c|c|}
\hline \multirow{2}{*}{ Model } & \multirow{2}{*}{ (Intercept) } & \multicolumn{16}{|c|}{$p$-Value } & \multirow[b]{2}{*}{ AIC } & \multirow{2}{*}{$\begin{array}{l}R^{2} \\
(\%)\end{array}$} \\
\hline & & $\begin{array}{c}\text { Flow } \\
\text { Velocity }\end{array}$ & $\mathrm{BOD}_{5}$ & Turbidity & $\begin{array}{l}\text { Mean } \\
\text { Depth }\end{array}$ & Temperature & $\mathrm{pH}$ & DO & Color & Conductivity & COD & $\begin{array}{l}\text { Nitrate. } \\
\text { Nitrite }\end{array}$ & $\begin{array}{l}\text { Ammonia } \\
\text { Nitrogen }\end{array}$ & $\begin{array}{c}\text { Organic } \\
\text { Nitrogen }\end{array}$ & $\begin{array}{l}\text { Total } \\
\text { Solids }\end{array}$ & $\begin{array}{l}\text { Log Fecal } \\
\text { Coliforms }\end{array}$ & Phosphates & & \\
\hline $\mathrm{m} 10$ & 0.90 & - & - & 0.31 & - & 0.06 & 0.38 & 0.38 & 0.24 & 0.40 & 0.51 & 0.10 & 0.98 & 0.29 & - & 0.45 & - & 39 & 66 \\
\hline $\mathrm{m} 11$ & 0.90 & - & - & 0.31 & - & 0.06 & 0.38 & 0.38 & 0.24 & 0.40 & 0.51 & 0.10 & - & 0.29 & - & 0.45 & - & 37 & 66 \\
\hline $\mathrm{m} 12$ & 0.84 & - & - & 0.21 & - & 0.04 & 0.49 & 0.53 & 0.24 & 0.44 & - & 0.09 & - & 0.17 & - & 0.39 & - & 35 & 65 \\
\hline $\mathrm{m} 13$ & 0.79 & - & - & 0.22 & - & 0.05 & 0.63 & - & 0.21 & 0.42 & - & 0.10 & - & 0.17 & - & 0.53 & - & 34 & 64 \\
\hline $\mathrm{m} 14$ & 0.07 & - & 0.51 & 0.20 & - & 0.03 & - & - & 0.32 & 0.49 & - & 0.18 & - & 0.20 & - & 0.31 & - & 34 & 64 \\
\hline $\mathrm{m} 15$ & 0.02 & - & - & 0.88 & - & 0.02 & - & - & 0.42 & - & - & 0.52 & - & 0.49 & - & - & - & 43 & 29 \\
\hline $\mathrm{m} 16$ & 0.05 & 0.75 & 0.57 & - & 0.88 & 0.07 & - & - & 0.68 & - & - & - & - & 0.46 & - & - & - & 44 & 31 \\
\hline $\mathrm{m} 160$ & 0.05 & 0.78 & 0.54 & - & - & 0.07 & - & - & 0.70 & - & - & - & - & 0.45 & - & - & - & 42 & 31 \\
\hline m161 & 0.05 & - & 0.53 & - & - & 0.07 & - & - & 0.75 & - & - & - & - & 0.43 & - & - & - & 40 & 31 \\
\hline m162 & 0.05 & - & 0.43 & - & - & 0.07 & - & - & - & - & - & - & - & 0.29 & - & - & - & 38 & 30 \\
\hline m163 & 0.02 & - & - & - & - & 0.02 & - & - & - & - & - & - & - & 0.23 & - & - & - & 39 & 24 \\
\hline m164 & 0.52 & - & - & - & - & - & - & - & - & - & - & - & - & 0.33 & - & - & - & 46 & 4 \\
\hline m165 & 0.05 & - & - & - & - & 0.07 & - & 0.52 & - & - & - & - & - & - & - & 0.08 & - & 40 & 26 \\
\hline m166 & 0.02 & - & - & 0.52 & - & 0.02 & - & - & - & - & - & - & - & 0.23 & - & 0.00 & - & 41 & 25 \\
\hline m167 & 0.03 & - & - & - & - & 0.05 & - & - & - & - & - & - & - & 0.27 & - & 0.11 & - & 37 & 32 \\
\hline m168 & 0.03 & - & - & - & - & 0.04 & - & 0.51 & - & - & - & - & - & 0.26 & - & 0.10 & - & 39 & 33 \\
\hline m169 & 0.16 & 0.83 & 0.06 & - & - & - & - & - & - & - & - & - & - & - & - & 0.00 & - & 41 & 19 \\
\hline $\mathrm{m} 170$ & 0.14 & - & 0.06 & - & - & - & - & - & - & - & - & - & - & - & - & 0.00 & - & 39 & 19 \\
\hline m171 & 0.08 & - & 0.20 & - & - & 0.14 & - & - & - & - & - & - & - & - & - & 0.00 & - & 39 & 25 \\
\hline $\mathrm{m} 172$ & 0.10 & - & 0.21 & - & - & 0.00 & - & - & - & - & - & - & - & - & - & 0.32 & - & 40 & 22 \\
\hline m173 & 0.07 & - & 0.48 & - & - & 0.15 & - & - & - & - & - & - & - & - & - & 0.34 & - & 40 & 27 \\
\hline m174 & 0.04 & - & 0.72 & - & - & 0.07 & - & - & - & - & - & - & - & 0.28 & - & 0.32 & - & 39 & 33 \\
\hline m175 & 0.03 & - & - & - & - & 0.02 & - & - & - & - & - & - & - & - & - & - & - & 41 & 15 \\
\hline m176 & 0.99 & - & - & 0.10 & - & - & - & - & - & - & 0.17 & - & - & - & - & 0.09 & 1.00 & 40 & 30 \\
\hline m177 & 0.13 & - & - & 0.18 & - & - & - & - & - & - & 0.14 & - & - & - & 0.56 & 0.09 & - & 41 & 29 \\
\hline $\mathrm{m} 178$ & 0.42 & - & - & 0.17 & - & - & - & - & - & 0.28 & 0.22 & - & - & - & - & 0.07 & - & 40 & 31 \\
\hline m179 & 0.79 & - & - & 0.13 & - & - & 0.90 & - & - & 0.00 & 0.09 & - & - & - & - & 0.09 & - & 41 & 28 \\
\hline m1601 & 0.04 & - & - & 0.11 & - & - & - & - & - & 0.00 & 0.08 & - & - & - & - & 0.09 & - & 39 & 28 \\
\hline m1602 & 0.03 & - & - & 0.12 & - & 0.08 & - & - & - & 0.00 & 0.07 & - & - & - & - & 0.16 & - & 37 & 37 \\
\hline m1603 & 0.03 & - & - & 0.38 & - & 0.04 & - & - & - & 0.00 & 0.04 & - & - & - & - & - & - & 39 & 29 \\
\hline m1604 & 0.03 & - & - & - & - & 0.05 & - & - & - & 0.00 & 0.06 & - & - & - & - & - & - & 38 & 27 \\
\hline m1605 & 0.04 & - & - & - & - & 0.08 & - & - & - & 0.00 & 0.15 & - & - & - & - & 0.28 & - & 38 & 31 \\
\hline m1606 & 0.03 & - & - & - & - & 0.06 & - & 0.24 & - & 0.00 & 0.10 & - & - & - & - & 0.23 & - & 39 & 34 \\
\hline m1607 & 0.03 & - & - & - & - & 0.04 & - & 0.32 & - & 0.00 & 0.04 & - & - & - & - & - & - & 38 & 30 \\
\hline m1608 & 0.20 & - & - & - & - & 0.05 & 0.98 & - & - & 0.00 & 0.06 & - & - & - & - & - & - & 40 & 27 \\
\hline m1609 & 0.03 & - & - & - & - & 0.04 & - & - & - & 0.00 & 0.08 & 0.52 & - & - & - & - & - & 39 & 29 \\
\hline m1610 & 0.99 & - & - & - & - & 0.06 & - & - & - & 0.00 & 0.12 & - & - & - & - & - & 1.00 & 39 & 29 \\
\hline m1611 & 0.04 & - & - & - & - & 0.04 & - & - & - & 0.22 & 0.06 & - & - & - & - & - & - & 38 & 31 \\
\hline m1612 & 0.03 & 0.54 & - & - & - & 0.04 & - & - & - & - & 0.05 & - & - & - & - & - & - & 39 & 28 \\
\hline $\mathrm{m} 1613$ & 0.03 & - & - & - & 0.89 & 0.06 & - & - & - & - & 0.06 & - & - & - & - & - & - & 39 & 27 \\
\hline
\end{tabular}


Table A5. Cont.

\begin{tabular}{|c|c|c|c|c|c|c|c|c|c|c|c|c|c|c|c|c|c|c|c|}
\hline \multirow[b]{2}{*}{ Model } & \multirow{2}{*}{ (Intercept) } & \multicolumn{16}{|c|}{$p$-Value } & \multirow[b]{2}{*}{ AIC } & \multirow{2}{*}{$\begin{array}{l}R^{2} \\
(\%)\end{array}$} \\
\hline & & $\begin{array}{c}\text { Flow } \\
\text { Velocity }\end{array}$ & $\mathrm{BOD}_{5}$ & Turbidity & $\begin{array}{l}\text { Mean } \\
\text { Depth }\end{array}$ & Temperature & $\mathrm{pH}$ & DO & Color & Conductivity & COD & $\begin{array}{l}\text { Nitrate. } \\
\text { Nitrite }\end{array}$ & $\begin{array}{l}\text { Ammonia } \\
\text { Nitrogen }\end{array}$ & $\begin{array}{c}\text { Organic } \\
\text { Nitrogen }\end{array}$ & $\begin{array}{c}\text { Total } \\
\text { Solids }\end{array}$ & $\begin{array}{c}\text { Log Fecal } \\
\text { Coliforms }\end{array}$ & Phosphates & & \\
\hline m1614 & 0.04 & - & - & - & - & 0.04 & - & - & - & - & 0.09 & - & - & - & 0.60 & - & - & 39 & 28 \\
\hline m1615 & 0.03 & - & - & - & - & 0.04 & - & - & 0.54 & - & 0.28 & - & - & - & - & - & - & 39 & 28 \\
\hline $\mathrm{m} 1615^{\prime}$ & 0.06 & - & 0.51 & - & - & 0.12 & - & - & - & - & 0.19 & - & - & - & - & - & - & 39 & 29 \\
\hline $\mathrm{m} 1616$ & 0.04 & 0.23 & 0.96 & 0.22 & - & 0.03 & - & 0.22 & - & 0.19 & 0.25 & 0.88 & - & - & - & 0.12 & - & 40 & 54 \\
\hline m1617 & 0.03 & 0.21 & - & 0.19 & - & 0.03 & - & 0.19 & - & 0.18 & 0.21 & 0.89 & - & - & - & 0.09 & - & 38 & 54 \\
\hline m1618 & 0.03 & 0.14 & - & 0.18 & - & 0.03 & - & 0.18 & - & 0.17 & 0.19 & - & - & - & - & 0.07 & - & 36 & 53 \\
\hline m1619 & 0.04 & 0.25 & - & 0.66 & - & 0.03 & - & 0.57 & - & 0.04 & - & - & - & - & - & 0.02 & - & 38 & 45 \\
\hline m1620 & 0.04 & 0.16 & - & - & - & 0.02 & - & 0.59 & - & 0.04 & - & - & - & - & - & 0.02 & - & 36 & 44 \\
\hline m1621 & 0.03 & 0.17 & - & - & - & 0.02 & - & - & - & 0.04 & - & - & - & - & - & 0.02 & - & 35 & 44 \\
\hline $\mathrm{m} 1622$ & 0.04 & - & - & - & - & 0.04 & - & - & - & 0.06 & - & - & - & - & - & 0.04 & - & 35 & 38 \\
\hline $\mathrm{m} 1623$ & 0.04 & - & - & - & - & 0.08 & - & - & - & - & - & - & - & - & - & 0.09 & - & 38 & 25 \\
\hline $\mathrm{m} 1624$ & 0.14 & - & 0.06 & - & - & - & - & - & - & - & - & - & - & - & - & - & - & 39 & 19 \\
\hline m1625 & 0.12 & - & - & - & - & - & - & - & - & - & - & - & - & - & - & 0.04 & - & 40 & 17 \\
\hline
\end{tabular}


A

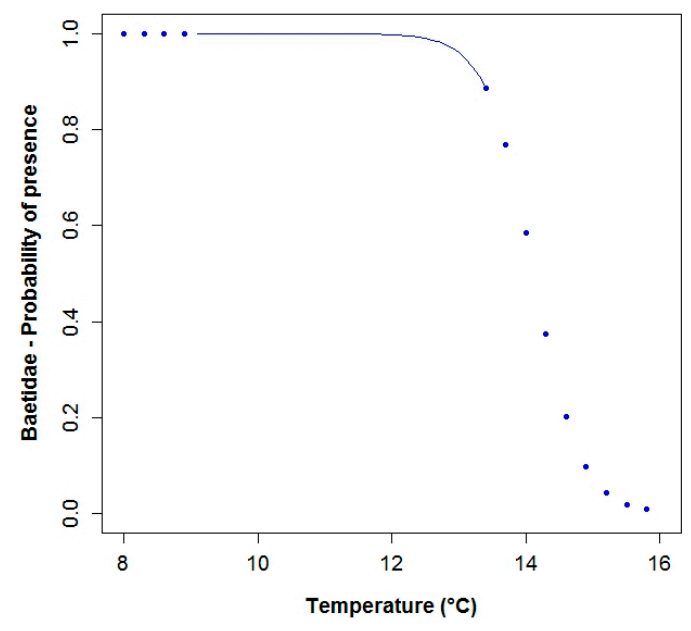

B

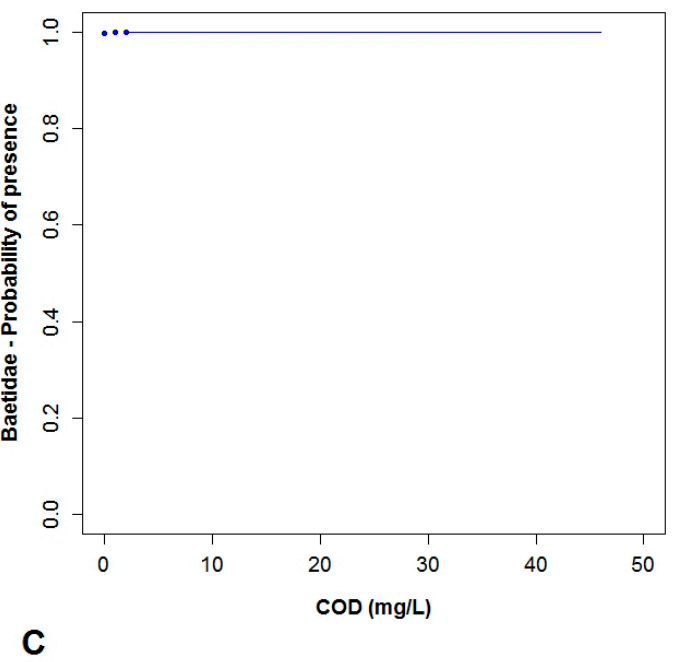

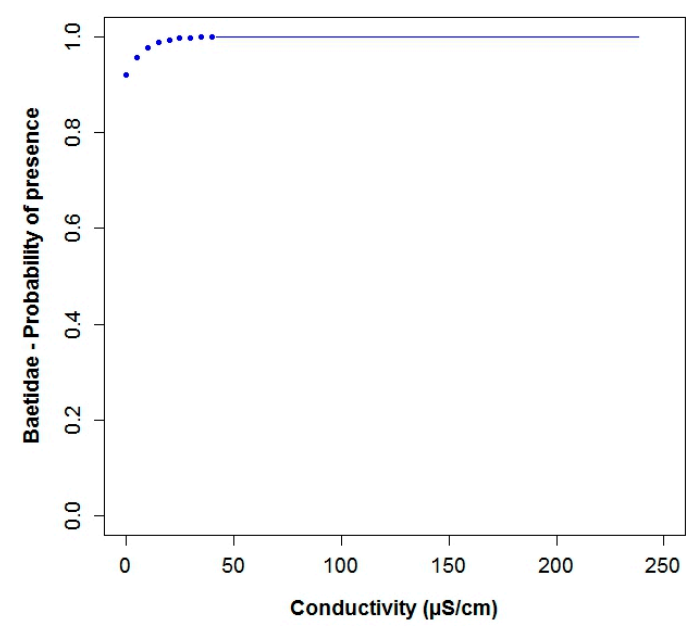

Figure A9. The probability of Baetidae being present in relation to (A) temperature; (B) COD; (C) conductivity. (The blue points in the curves indicate extrapolation outside the observed physicochemical variables range).

A

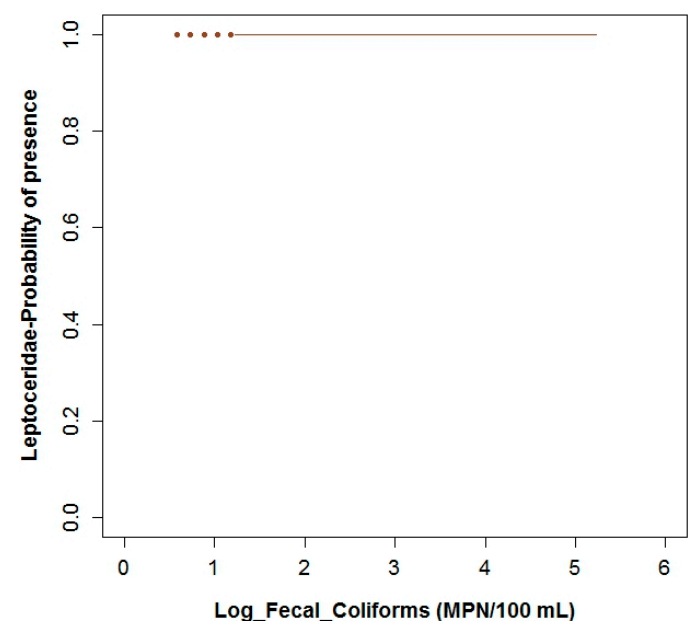

B

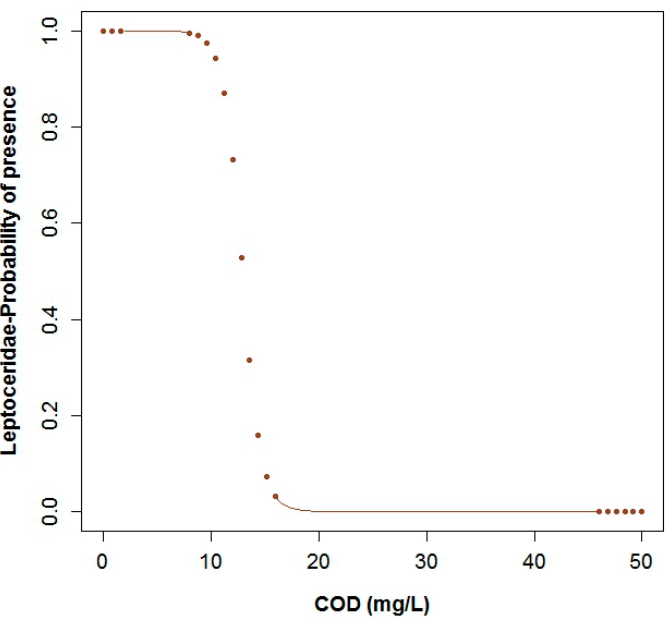

Figure A10. Cont. 
C

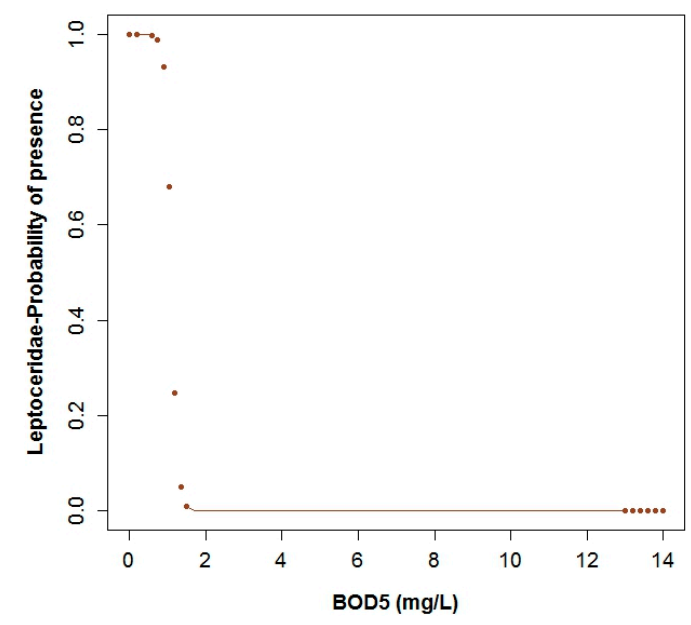

D

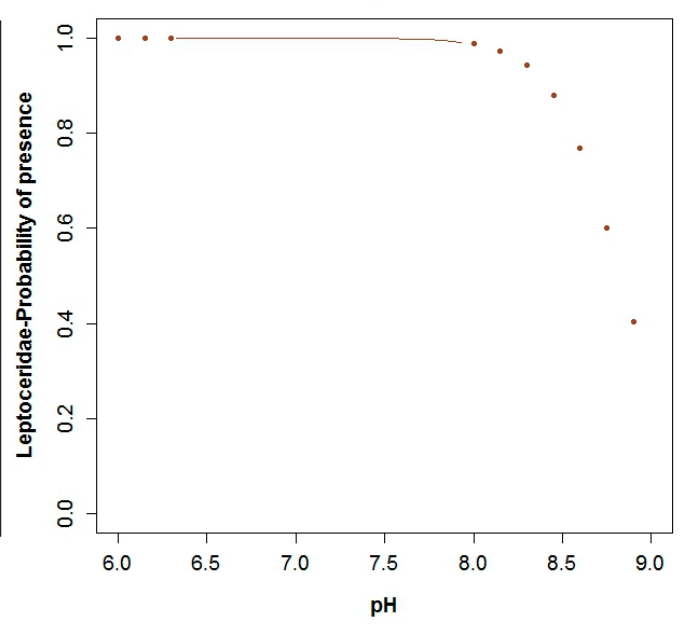

Figure A10. The probability of Leptoceridae being present in relation to (A) log fecal coliforms; (B) COD; (C) $\mathrm{BOD}_{5} ;(\mathrm{D}) \mathrm{pH}$. (The brown points in the curves indicate extrapolation outside the observed physicochemical variables) range.

A

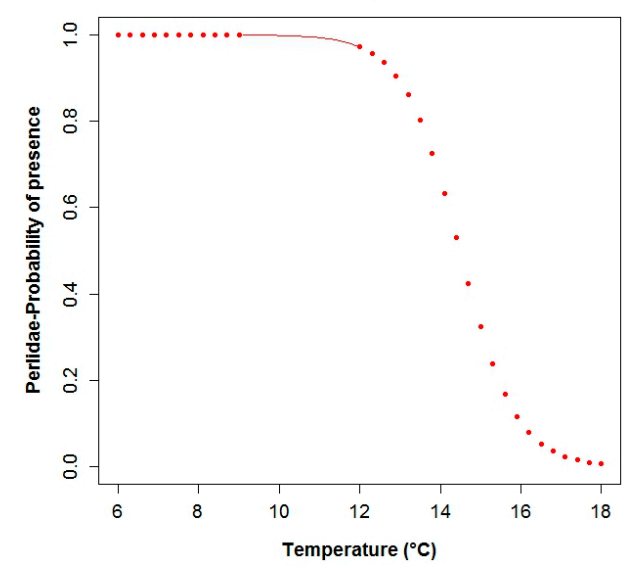

B

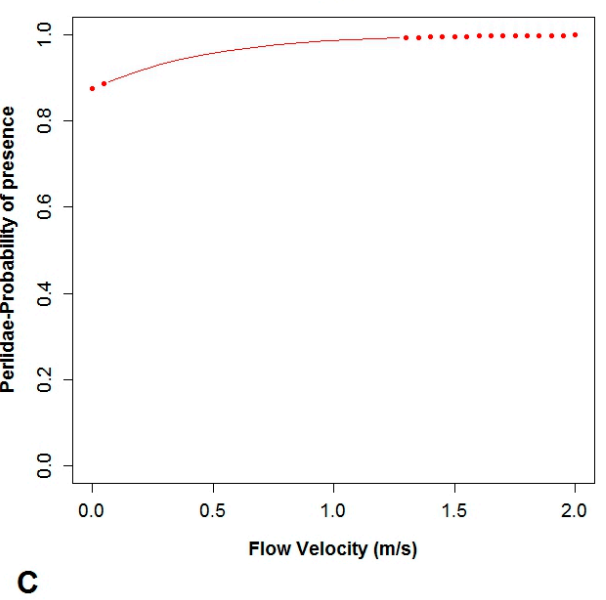

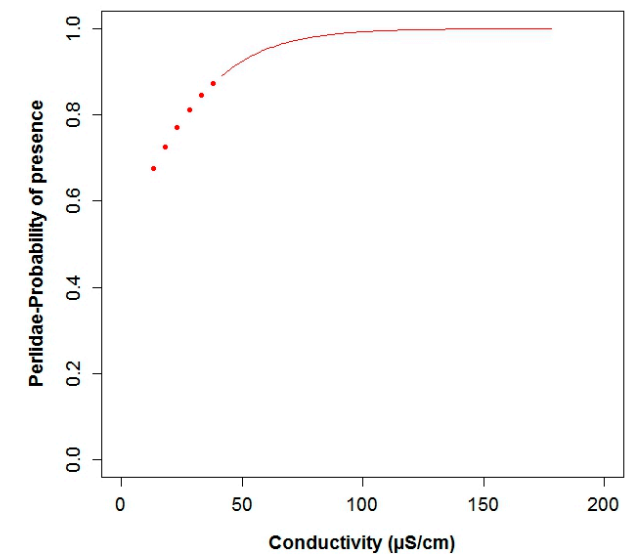

Figure A11. The probability of Perlidae being present in relation to: (A) temperature; (B) flow velocity; (C) conductivity. (The red points in the curves indicate extrapolation outside the observed physicochemical variables range). 
A

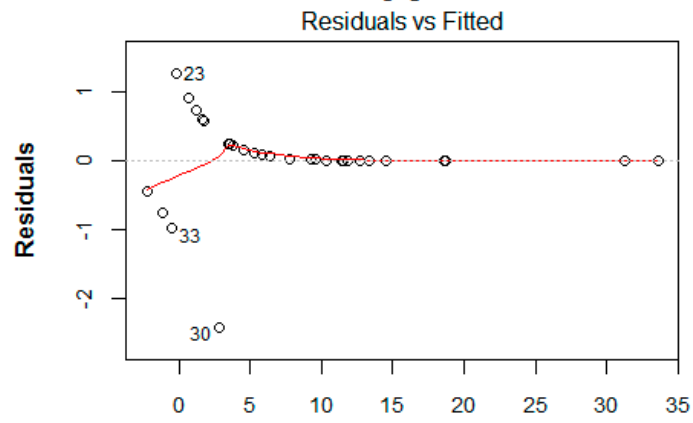

Predicted values

glm(Baetidae Temperature + True_Color + Conductivity + COD)

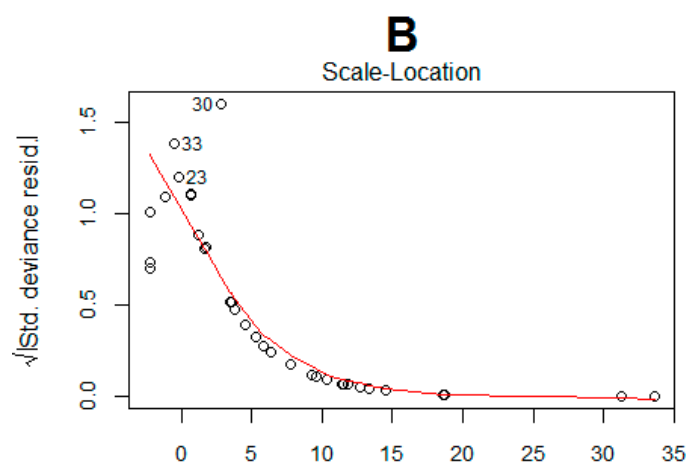

Predicted values

glm(Baetidae $\sim$ Temperature + True_Color + Conductivity + COD)

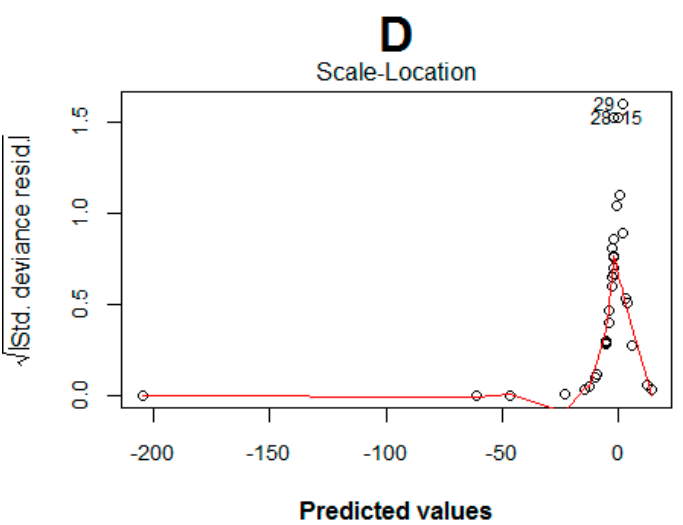

glm(Leptoceridae $\sim$ Log_F_Coliforms + FI_Velocity + BODS + pH + COD + Conduc ..

$\mathbf{F}$

Scale-Location

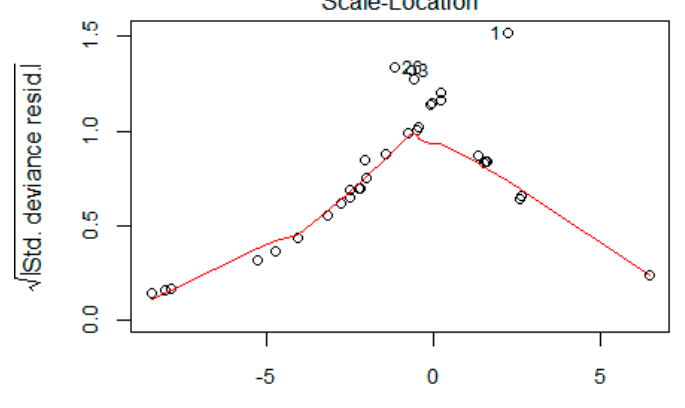

Predicted values

glm(Perlidae $\sim$ Temperature + Log_F_Coliforms + Conduct + FI_Velocity $)$

glm(Perlidae $\sim$ Temperature + Log_F_Coliforms + Conduct + FI_Velocity)

Figure A12. Plots of Residual vs. Fitted (A) Baetidae; (C) Leptoceridae; (E) Perlidae and plots of Scale-Location of (B) Baetidae; (D) Leptocerida and (F) Perlidae.

\section{References}

1. Ambelu, A.; Lock, K.; Goethals, P. Comparison of modelling techniques to predict macroinvertebrate community composition in rivers of Ethiopia. Ecol. Inform. 2010, 5, 147-152. [CrossRef]

2. Džeroski, S.; Demšar, D.; Grbović, J. Predicting chemical parameters of river water quality from bioindicator data. Appl. Intell. 2000, 13, 7-17.

3. De Pauw, N.; Gabriels, W.; Goethals, P.L. Goethals, River monitoring and assessment methods based on macroinvertebrates. In Biological Monitoring of Rivers; John Wiley \& Sons: Chichester, UK, 2006; pp. 113-134.

4. Rosenberg, D.M.; Resh, V.H. Freshwater Biomonitoring and Benthic Macroinvertebrates; Chapman \& Hall: London, UK, 1993. 
5. Junqueira, V.; Campos, S. Adaptation of the "BMWP" method for water quality evaluation to Rio das Velhas watershed (Minas Gerais, Brazil). Acta Limnol. Bras. 1998, 10, 125-135.

6. Mustow, S. Biological monitoring of rivers in Thailand: Use and adaptation of the BMWP score. Hydrobiologia 2002, 479, 191-229. [CrossRef]

7. Roldán Pérez, G.A. Bioindicación de la Calidad del Agua en Colombia: Uso del Método BMWP/Col; Imprenta Universidad de Antioquia: Medellín, Colombia, 2003.

8. Hvitved-Jacobsen, T. The impact of combined sewer overflows on the dissolved oxygen concentration of a river. Water Res. 1982, 16, 1099-1105. [CrossRef]

9. Lenat, D.R.; Resh, V.H. Taxonomy and stream ecology-The benefits of genus-and species-level identifications. J. N. Am. Benthol. Soc. 2001, 20, 287-298. [CrossRef]

10. Thorne, R.; Williams, P. The response of benthic macroinvertebrates to pollution in developing countries: A multimetric system of bioassessment. Freshw. Biol. 1997, 37, 671-686. [CrossRef]

11. Ríos-Touma, B.; Encalada, A.C.; Prat Fornells, N. Macroinvertebrate Assemblages of an Andean High-Altitude Tropical Stream: The Importance of Season and Flow. Int. Rev. Hydrobiol. 2011, 96, 667-685.

12. Jacobsen, D.; Marín, R. Bolivian Altiplano streams with low richness of macroinvertebrates and large diel fluctuations in temperature and dissolved oxygen. Aquat. Ecol. 2008, 42, 643-656. [CrossRef]

13. Jacobsen, D.; Rostgaard, S.; Vásconez, J.J. Are macroinvertebrates in high altitude streams affected by oxygen deficiency? Freshw. Biol. 2003, 48, 2025-2032. [CrossRef]

14. Jacobsen, D. The effect of organic pollution on the macroinvertebrate fauna of Ecuadorian highland streams. Arch. Hydrobiol. 1998, 143, 179-195.

15. Degraer, S.; Verfaillie, E.; Willems, W.; Adriaens, E.; Vincx, M.; Van Lancker, V. Habitat suitability modelling as a mapping tool for macrobenthic communities: An example from the Belgian part of the North Sea. Cont. Shelf Res. 2008, 28, 369-379. [CrossRef]

16. Zarkami, R. Habitat Suitability Modelling of Pike (Esox lucius) in Rivers; Ghent University: Ghent, Belgium, 2008.

17. Dominguez-Granda, L.; Lock, K.; Goethals, P.L. Using multi-target clustering trees as a tool to predict biological water quality indices based on benthic macroinvertebrates and environmental parameters in the Chaguana watershed (Ecuador). Ecol. Inform. 2011, 6, 303-308. [CrossRef]

18. Goethals, P. Data Driven Development of Predictive Ecological Models for Benthic Macroinvertebrates in Rivers; Ghent University: Ghent, Belgium, 2005.

19. Fernández de Córdova, J.; González, H. Evoluación de la Calidad del Agua de los Tramos Bajos de los Ríos de la Ciudad de Cuenca; ETAPA-EP: Cuenca, Ecuador, 2012.

20. Instituto Nacional de Estadísticas y Censos del Ecuador (INEC). Proyección de la Población Ecuatoriana, por años Calendario, Según Cantones 2010-2020; Instituto Nacional de Estadísticas y Censos del Ecuador: Quito, Ecuador, 2010.

21. PROMAS-UCuenca. Información de la Red Meteorológica e Hidrológica; Programa para el Manejo del Agua y el Suelo; Universidad de Cuenca: Cuenca, Ecuador, 2010.

22. Aeropuerto_Mariscal_Lamar. Información Meteorológica Aeropuerto Mariscal Lamar Cuenca; Dirección de Aviación Civil del Ecuador: Quito, Ecuador, 2012.

23. Estrella, R.; Tobar, V. Hidrología y Climatología-Formulación del Plan de Manejo Integral de la Subcuenca del río Machangara; ACOTECNIC Cia. Ltda.-Consejo de Cuenca del Rio Machangara: Cuenca, Ecuador, 2013.

24. Esquivel, J.C.; Verbeiren, B.; Alvarado, A.; Feyen, J.; Cisneros, F. Preliminary Statistical Analysis of the Water Quality Database of ETAPA; PROMAS-Universidad de Cuenca: Cuenca, Ecuador, 2008.

25. Mulliss, R.; Revitt, D.M.; Shutes, R.B.E. The impacts of discharges from two combined sewer overflows on the water quality of an urban watercourse. Water Sci. Technol. 1997, 36, 195-199. [CrossRef]

26. Weyrauch, P.; Matzinger, A.; Pawlowsky-Reusing, E.; Plume, S.; von Seggern, D.; Heinzmann, B.; Schroeder, K.; Rouault, P. Contribution of combined sewer overflows to trace contaminant loads in urban streams. Water Res. 2010, 44, 4451-4462. [CrossRef] [PubMed]

27. Passerat, J.; Ouattara, N.K.; Mouchel, J.-M.; Vincent, R.; Servais, P. Impact of an intense combined sewer overflow event on the microbiological water quality of the Seine River. Water Res. 2011, 45, 893-903. [CrossRef] [PubMed]

28. Novotny, V. Diffuse pollution from agriculture-A worldwide outlook. Water Sci. Technol. 1999, 39 , 1-13. [CrossRef] 
29. Armitage, P.D.; Moss, D.; Wright, J.F.; Furse, M.T. The performance of a new biological water quality score system based on macroinvertebrates over a wide range of unpolluted running-water sites. Water Res. 1983, 17, 333-347. [CrossRef]

30. Sutherland, W.J. Ecological Census Techniques: A Handbook; Cambridge University Press: Cambridge, UK, 2006.

31. Alba-Tecedor, J.; Pardo, I.; Prat, N.; Pujanta, A. Protocolos de Muestreo y Análisis para Invertebrados Bentónicos; Ministerio de Medio Ambiente, Confederación Hidrográfica del Ebro y URS, Metodología para el establecimiento del Estado Ecológico según la Directiva Marco del Aguas: Madrid, Spain, 2005.

32. Roldán Pérez, G.A. Guía Para el Estudio de los Macroinvertebrados Acuáticos del Departamento de Antioquia; Fondo para la Protección del Medio Ambiente José Celestino Mutis: Bogotá, Colombia, 1988.

33. Álvarez, L.F. Metodología Para la Utilización de los Macroinvertebrados Acuáticos Como Indicadores de la Calidad del Agua; Instituto Alexander von Humboldt: Bogotá, Colombia, 2006.

34. Encalada, A.C. Protocolo Simplificado y Guía de Evaluación de la Calidad Ecológica de ríos Andinos (CERA-S): Text; 2. Làmines; Proyecto FUCARA: Quito, Ecuador, 2011.

35. Zúñiga, M.D.C.; Cardona, W.; Cantera, J.; Carvajal, Y.; Castro, L. Bioindicadores de calidad de agua y caudal ambiental. In Caudal Ambiental: Conceptos Experiencias Desafíos; Programa Editorial, Universidad del Valle: Cali, Colombia, 2009; Volume 1, pp. 167-197.

36. Zuur, A.; Ieno, E.N.; Walker, N.; Saveliev, A.A.; Smith, G.M. Mixed Effects Models and Extensions in Ecology with R; Springer: New York, NY, USA, 2009.

37. Holguin-Gonzalez, J.E.; Everaert, G.; Boets, P.; Galvis, A.; Goethals, P.L. Development and application of an integrated ecological modelling framework to analyze the impact of wastewater discharges on the ecological water quality of rivers. Environ. Model. Softw. 2013, 48, 27-36. [CrossRef]

38. Everaert, G.; de Neve, J.; Boets, P.; Dominguez-Granda, L.; Mereta, S.T.; Ambelu, A.; Hoang, T.H.; Goethals, P.L.M.; Thas, O. Comparison of the abiotic preferences of macroinvertebrates in tropical river basins. PLoS ONE 2014, 9, e108898. [CrossRef] [PubMed]

39. Nguyen, H.H.; Everaert, G.; Gabriels, W.; Hoang, T.H.; Goethals, P.L. A multimetric macroinvertebrate index for assessing the water quality of the Cau river basin in Vietnam. Limnol.-Ecol. Manag. Inland Waters 2014, 45, 16-23. [CrossRef]

40. Hering, D.; Feld, C.K.; Moog, O.; Ofenböck, T. Cook book for the development of a Multimetric Index for biological condition of aquatic ecosystems: Experiences from the European AQEM and STAR projects and related initiatives. Hydrobiologia 2006, 566, 311-324. [CrossRef]

41. Booth, G.D.; Niccolucci, M.J.; Schuster, E.G. Identifying Proxy Sets in Multiple Linear Regression: An Aid to Better Coefficient Interpretation; U.S. Dept. of Agriculture, Forest Service, Intermountain Research Station: Ogden, UT, USA, 1994.

42. Agresti, A.; Kateri, M. Categorical Data Analysis; Springer-Verlag: Berlin/Heidelberg, Germany, 2011.

43. Gabriels, W.; Goethals, P.L.; Dedecker, A.P.; Lek, S.; De Pauw, N. Analysis of macrobenthic communities in Flanders, Belgium, using a stepwise input variable selection procedure with artificial neural networks. Aquat. Ecol. 2007, 41, 427-441. [CrossRef]

44. Hu, B.; Shao, J.; Palta, M. Pseudo-R 2 in logistic regression model. Stat. Sin. 2006, 16, 847-860.

45. R-Core-Team. A Language and Environment for Statistical Computing; R Foundation for Statistical Computing: Vienna, Austria, 2015.

46. Kasangaki, A.; Chapman, L.J.; Balirwa, J. Land use and the ecology of benthic macroinvertebrate assemblages of high-altitude rainforest streams in Uganda. Freshw. Biol. 2008, 53, 681-697. [CrossRef]

47. Beadle, L.C. The Inland Waters of Tropical Africa: An Introduction to Tropical Limnology; Longman Group Ltd. Publishers: London, UK, 1974.

48. Acreman, M.; Ferguson, A. Environmental flows and the European water framework directive. Freshw. Biol. 2010, 55, 32-48. [CrossRef]

49. Ogleni, N.; Topal, B. Water quality assessment of the Mudurnu River, Turkey, using biotic indices. Water Resour. Manag. 2011, 25, 2487. [CrossRef]

50. Forio, M.A.E.; Van Echelpoel, W.; Dominguez-Granda, L.; Mereta, S.T.; Ambelu, A.; Hoang, T.H.; Boets, P.; Goethals, P.L. Analysing the effects of water quality on the occurrence of freshwater macroinvertebrate taxa among tropical river basins from different continents. AI Commun. 2016, 29, 665-685. [CrossRef]

51. D'Heygere, T.; Goethals, P.L.M.; De Pauw, N. Use of genetic algorithms to select input variables in decision tree models for the prediction of benthic macroinvertebrates. Ecol. Model. 2003, 160, 291-300. 
52. Schwarzenbach, R.P.; Egli, T.; Hofstetter, T.B.; von Gunten, U.; Wehrli, B. Global water pollution and human health. Annu. Rev. Environ. Resour. 2010, 35, 109-136. [CrossRef]

53. Lock, K.; Goethals, P.L. Habitat suitability modelling for mayflies (Ephemeroptera) in Flanders (Belgium). Ecol. Inform. 2013, 17, 30-35. [CrossRef]

54. Lock, K.; Goethals, P.L. Distribution and ecology of the caddisflies (Trichoptera) of Flanders (Belgium). Ann. Limnol.-Int. J. Limnol. 2012, 48, 31-37. [CrossRef]

55. Lock, K.; Goethals, P.L. Distribution and ecology of the stoneflies (Plecoptera) of Flanders (Belgium). Ann. Limnol.-Int. J. Limnol. 2008, 44, 203-213. [CrossRef]

56. Dedecker, A.P.; Goethals, P.L.; Gabriels, W.; De Pauw, N. Optimization of Artificial Neural Network (ANN) model design for prediction of macroinvertebrates in the Zwalm river basin (Flanders, Belgium). Ecol. Model. 2004, 174, 161-173. [CrossRef]

57. Holguin-Gonzalez, J.E.; Boets, P.; Alvarado, A.; Cisneros, F.; Carrasco, M.C.; Wyseure, G.; Nopens, I.; Goethals, P.L. Integrating hydraulic, physicochemical and ecological models to assess the effectiveness of water quality management strategies for the River Cuenca in Ecuador. Ecol. Model. 2013, 254, 1-14. [CrossRef]

58. Connolly, N.; Crossland, M.; Pearson, R. Effect of low dissolved oxygen on survival, emergence, and drift of tropical stream macroinvertebrates. J. N. Am. Benthol. Soc. 2004, 23, 251-270. [CrossRef]

59. Chakona, A.; Phiri, C.; Day, J.A. Potential for Trichoptera communities as biological indicators of morphological degradation in riverine systems. Hydrobiologia 2009, 621, 155-167. [CrossRef]

60. Hawkins, C.P.; Hogue, J.N.; Decker, L.M.; Feminella, J.W. Channel morphology, water temperature, and assemblage structure of stream insects. J. N. Am. Benthol. Soc. 1997, 16, 728-749. [CrossRef]

61. Hynes, H.B.N. The Biology of Polluted Waters; Liverpool UP: Liverpool, UK, 1960.

62. Burneo, P.C.; Gunkel, G. Ecology of a high Andean stream, Rio Itambi, Otavalo, Ecuador. Limnol.-Ecol. Manag. Inland Waters 2003, 33, 29-43. [CrossRef]

63. Bennett, L.E.; Drikas, M. The evaluation of colour in natural waters. Water Res. 1993, 27, $1209-1218$. [CrossRef]

64. Haaland, S.; Hongve, D.; Laudon, H.; Riise, G.; Vogt, R. Quantifying the drivers of the increasing colored organic matter in boreal surface waters. Environ. Sci. Technol. 2010, 44, 2975-2980. [CrossRef] [PubMed]

65. Dallas, H.F.; Day, J.A. Natural variation in macroinvertebrate assemblages and the development of a biological banding system for interpreting bioassessment data-A preliminary evaluation using data from upland sites in the south-western Cape, South Africa. Hydrobiologia 2007, 575, 231-244. [CrossRef]

66. Feldman, R.S.; Connor, E.F. The relationship between $\mathrm{pH}$ and community structure of invertebrates in streams of the Shenandoah National Park, Virginia, USA. Freshw. Biol. 1992, 27, 261-276. [CrossRef]

67. Ambelu, A.; Mekonen, S.; Koch, M.; Addis, T.; Boets, P.; Everaert, G.; Goethals, P. The application of predictive modelling for determining bio-environmental factors affecting the distribution of blackflies (Diptera: Simuliidae) in the Gilgel Gibe watershed in Southwest Ethiopia. PLoS ONE 2014, 9, e112221. [CrossRef] [PubMed]

68. Damanik-Ambarita, M.N.; Everaert, G.; Forio, M.A.E.; Nguyen, T.H.T.; Lock, K.; Musonge, P.L.S.; Suhareva, N.; Dominguez-Granda, L.; Bennetsen, E.; Boets, P.; et al. Generalized Linear Models to Identify Key Hydromorphological and Chemical Variables Determining the Occurrence of Macroinvertebrates in the Guayas River Basin (Ecuador). Water 2016, 8, 297. [CrossRef]

69. Thuiller, W. BIOMOD-Optimizing predictions of species distributions and projecting potential future shifts under global change. Glob. Chang. Biol. 2003, 9, 1353-1362. [CrossRef]

70. Vaughan, I.P.; Ormerod, S.J. The continuing challenges of testing species distribution models. J. Appl. Ecol. 2005, 42, 720-730. [CrossRef]

71. Stockwell, D.R.; Peterson, A.T. Effects of sample size on accuracy of species distribution models. Ecol. Model. 2002, 148, 1-13. [CrossRef]

72. Yu, R.; Abdel-Aty, M. Utilizing support vector machine in real-time crash risk evaluation. Accid. Anal. Prev. 2013, 51, 252-259. [CrossRef] [PubMed] 
73. Pearce, J.; Ferrier, S. Evaluating the predictive performance of habitat models developed using logistic regression. Ecol. Model. 2000, 133, 225-245. [CrossRef]

74. Manel, S.; Williams, H.C.; Ormerod, S.J. Evaluating presence-absence models in ecology: The need to account for prevalence. J. Appl. Ecol. 2001, 38, 921-931. [CrossRef]

75. Mac Nally, R. Regression and model-building in conservation biology, biogeography and ecology: The distinction between-and reconciliation of 'predictive' and 'explanatory' models. Biodivers. Conserv. 2000, 9, 655-671. [CrossRef]

(C) 2017 by the authors. Licensee MDPI, Basel, Switzerland. This article is an open access article distributed under the terms and conditions of the Creative Commons Attribution (CC BY) license (http://creativecommons.org/licenses/by/4.0/). 